

\title{
The vasoactive peptides urotensin II and urotensin II-related peptide regulate astrocyte activity through common and distinct mechanisms. Involvement in cell proliferation
}

Marie Jarry, Mickael Diallo, Céline Lecointre, Laurence Desrues, Tursonjan Tokay, David Chatenet, Jérôme Leprince, Oriana Rossi, Hubert Vaudry, Marie-Christine Tonon, et al.

\section{- To cite this version:}

Marie Jarry, Mickael Diallo, Céline Lecointre, Laurence Desrues, Tursonjan Tokay, et al.. The vasoactive peptides urotensin II and urotensin II-related peptide regulate astrocyte activity through common and distinct mechanisms. Involvement in cell proliferation. Biochemical Journal, 2010, 428 (1), pp.113-124. 10.1042/BJ20090867 . hal-00479207

\section{HAL Id: hal-00479207 https://hal.science/hal-00479207}

Submitted on 30 Apr 2010

HAL is a multi-disciplinary open access archive for the deposit and dissemination of scientific research documents, whether they are published or not. The documents may come from teaching and research institutions in France or abroad, or from public or private research centers.
L'archive ouverte pluridisciplinaire HAL, est destinée au dépôt et à la diffusion de documents scientifiques de niveau recherche, publiés ou non, émanant des établissements d'enseignement et de recherche français ou étrangers, des laboratoires publics ou privés. 


\section{The vasoactive peptides Urotensin II and Urotensin II-related peptide regulate astrocyte activity through common and distinct mechanisms. Involvement in cell proliferation}

Marie Jarry ${ }^{\dagger 1}$, Mickaël Diallo ${ }^{\dagger 1}$, Céline Lecointre ${ }^{\dagger}$, Laurence Desrues ${ }^{\dagger}$, Tursonjan Tokay ${ }^{\dagger}$, David Chatenet ${ }^{\dagger \ddagger}$, Jérôme Leprince ${ }^{\dagger}$, Oriana Rossi ${ }^{\dagger}$, Hubert Vaudry $^{\dagger}$, Marie-Christine Tonon ${ }^{\dagger}$, Laurent Prézeau ${ }^{\S}$, Hélène Castel ${ }^{\dagger}$ and Pierrick Gandolfo $^{\dagger}$

${ }^{\dagger}$ EA4310, Inserm U982, "DC2N», Laboratory of Neuronal and Neuroendocrine Communication and Differentiation, Astrocyte and Vascular Niche, European Institute for Peptide Research (IFRMP 23), University of Rouen, Mont-Saint-Aignan, Normandy, France

${ }^{\ddagger}$ Institut National de la Recherche Scientifique-Institut Armand Frappier, University of Québec, Pointe-Claire, Canada H9RIG6

${ }^{\S}$ UMR CNRS 5203, Inserm U661, Institut of Functional Genomic, University of Montpellier 1 and 2, France

${ }^{1}$ These authors contributed equally

To whom correspondence should be addressed (e-mail: helene.castel@univ-rouen.fr) Current address : EA4310, Inserm U982, «DC2N », Laboratory of Neuronal and Neuroendocrine Communication and Differentiation, Astrocyte and Vascular Niche, University of Rouen, 76821 Mont-Saint-Aignan, Normandy, France

Short title: Differential effects of URP and UII on astrocyte proliferation

Keywords: UT receptor, calcium, proliferation, G protein, BRET 


\section{Abbreviations used}

2-APB, 2-aminoethoxydiphenylborane; BRET, Bioluminescence Resonance Energy Transfer; $\left[\mathrm{Ca}^{2+}\right]_{\mathrm{c}}$ cytosolic calcium concentration; $\omega$-CgTx GVIA, $\omega$-conotoxin GVIA; DBI, diazepam-binding inhibitor; DMEM, Dulbecco's modified Eagle's medium; EGTA, ethylene glycol-bis(2-aminoethylether)- $N, N, N^{\prime}, N^{\prime}$-tetraacetic acid; ET-1, endothelin-1; FBS, fetal bovine serum; GPCR, G protein-coupled receptor; IL-1 $\beta$, interleukin-1 $\beta$; ODN, octadecaneuropeptide; PAR, protease-activated receptor; PBS, phosphate buffered saline; PIP, polyphosphoinositides; PI3K, polyphosphoinositide kinase 3; PLC, phospholipase C; PKB, protein kinase B; PTX, pertussis toxin; Rluc, Renilla reniformis luciferase; Thr, Thrombin; UII, urotensin II; URP, urotensin IIrelated peptide; UT, UII receptor. 


\section{Synopsis}

Urotensin II (UII) and its paralog urotensin II-related peptide (URP) are two vasoactive neuropeptides whose respective central actions are currently unknown. Here, we have compared the mechanism of action of URP and UII on cultured astrocytes. Competition experiments performed with $\left[{ }^{125} \mathrm{I}\right] \mathrm{UII}$ showed the presence of very high- and high-affinity binding sites for UII, and a single high-affinity site for URP. Both UII and URP provoked a membrane depolarization accompanied by a decrease of input resistance, stimulated the release of endozepines, neuropeptides specifically produced by astroglial cells, and generated an increase in cytosolic calcium concentration $\left(\left[\mathrm{Ca}^{2+}\right]_{c}\right)$. The UII/URP-induced $\left[\mathrm{Ca}^{2+}\right]_{c}$ elevation was pertussis toxin (PTX)-insensitive, and was blocked by the PLC inhibitor U73122 or the $\mathrm{IP}_{3}$ channel blocker 2-APB. The addition of $\mathrm{Ca}^{2+}$ chelator EGTA reduced the peak and abolished the plateau phase whereas the T-type calcium channel blocker mibefradil totally inhibited the calcium response evoked by both peptides. However, URP and UII induced a mono- and biphasic dose-dependent increase in $\left[\mathrm{Ca}^{2+}\right]_{\mathrm{c}}$ and provoked short- and long-lasting $\mathrm{Ca}^{2+}$ mobilization, respectively. Similar mono- and biphasic dose-dependent increase in $\left[{ }^{3} \mathrm{H}\right]$ inositol incorporation into polyphosphoinositides (PIP) in astrocytes was obtained but sole the effect of UII was significantly reduced by PTX, although BRET experiments revealed that both UII and URP recruited $\mathrm{G}_{\mathrm{o}}$ protein. Finally, UII exerted a dose-dependent mitogenic activity on astrocytes, but not URP. Therefore, we described that URP and UII exert not only similar but also divergent actions on astrocyte activity, UII exhibiting a broader range of activities at physiological peptide concentrations.

\section{Introduction}

Urotensin II (UII) is a cyclic neuropeptide that has been initially isolated from the urophysis, a neurosecretory organ located in the caudal portion of the spinal cord of teleost fish [1]. Orthologs of UII have been subsequently characterized in the brain and spinal cord of various species of tetrapods including frog, mouse, rat, pig and human [2] . A paralog of UII called UII-related peptide (URP) has been recently identified in rat and 
human [3]. UII and URP share a fully conserved C-terminal cyclic hexapeptide CFWKYC core that plays a major role for the biological activity of the peptides [4]. The cyclic region of UII and URP exhibits some structural similarities to that of somatostatin (Fig. 1) and it has recently been found that the genes encoding these three neuropeptides originate from a common ancestor [5].

The mRNAs encoding the UII and URP precursors have been localized both in the brain and in peripheral organs [3]. In the rat and mouse central nervous system (CNS), the UII and URP genes are primarily expressed in subpopulations of motoneurons located in discrete brainstem nuclei and in the ventral horn of the spinal cord $[6,7]$. In the human brain, high levels URP mRNA are also present in the hippocampus and thalamus [3]. It has recently been shown that a mature form of UII in the rat brain could only imply atypical clivage sites in prepro-UII, and that URP might be the sole UII-immunoreactive substance present in the rodent brain [8].

The biological action of UII and URP are mediated through activation of a common G protein-coupled receptor originally called GPR14 [3, 9] and now renamed UT [2]. In UT-transfected CHO and HEK293 cells, UII stimulates the phospholipase C pathway and causes an increase in cytosolic calcium concentration $\left(\left[\mathrm{Ca}^{2+}\right]_{\mathrm{c}}\right)[10]$. UII also exerts mitogenic activity in UT-transfected cells and in vascular smooth muscle cells expressing native UT $[10,11]$.

In the CNS, UT mRNA has been detected in motoneurons of the spinal cord in mouse [12] and rat [13] as well as in the thalamus, superior occipital gyrus and substantia nigra in human [9]. Previous studies have shown that central administration of UII modulates cardiovascular, locomotor, behavioral and endocrine functions [14, 15]. Although URP has been proposed as the sole endogenous ligand for urotensinergic receptors in the brain [3], little is known regarding the central activities of URP.

It is now clearly established that astroglial cells release various neuroactive compounds [16] including the gliopeptides endozepines. Endozepines were originally characterized as endogenous ligands for benzodiazepine receptors [17]. All endozepines characterized so far derive from an 86-amino-acid precursor called diazepam-binding inhibitor (DBI) which generates several biologically active fragments, notably the octadecaneuropeptide $\left(\mathrm{ODN}, \mathrm{DBI}_{33-50}\right)$ [18]. The release of 
endozepines from astrocytes is regulated by several neuropeptides such as pituitary adenylate cyclase-activating polypeptide (PACAP) and somatostatin [19, 20].

The expression of UII and its receptor has been previously reported in a human glioblastoma cell line [21] and the presence of functional UT has been demonstrated in astrocytes [22, 23]. In astroglial cells, UII specifically binds two affinity sites, stimulates polyphosphoinositides (PIP) metabolism and causes a robust increase in $\left[\mathrm{Ca}^{2+}\right][22,24]$. Up to now, nothing is known regarding the mechanism of action of URP on native cells, and the relevance for the existence of a redundant peptide for a unique UT receptor remains unexplored. In the present study, we have characterized functional binding sites for URP on rat cortical astrocytes and compared the effects of URP with those of UII on electrophysiological activity, endozepine release, $\mathrm{Ca}^{2+}$, PIP turn-over and cell proliferation.

\section{Experimental}

Reagents

URP (ACFWKYCV), rat UII (UII, $p$ QHGTAPECFWKYCI) and rat octadecaneuropeptide ODN (diazepam-binding inhibitor 33-50, $\mathrm{DBI}_{33-50}$ ) were synthesized by the solid phase methodology on a Pioneer PerSeptive Biosystem peptide synthesizer (Applera France, Courtaboeuf, France) using the standard manufacturer's procedures as previously described [25]. All peptides were purified (> $98 \%$ ) on a $2.2 \times 25-\mathrm{cm} \mathrm{Vydac} \mathrm{C}_{18}$ column (Alltech, France) and characterized by MALDI-TOF MS on a Voyager DE-PRO mass spectrometer (Applera-France). Glutamine, N-2 hydroxyethylpiperazine-N'-2-ethane sulfonic acid (HEPES), the antibiotic-antimycotic solution and bovine $\gamma$-globulins were purchased from Invitrogen (Cergy-Pontoise, France). Dulbecco's modified Eagle's medium (DMEM), Ham-F12 culture medium, insulin, D(+)-glucose, mibefradil, nifedipine, $\omega$-conotoxine GVIA, pertussis toxin (PTX), endothelin-1 (ET-1), bovine serum albumin (BSA) were obtained from Sigma-Aldrich (St-Quentin Fallavier, France). Fetal bovine serum (FBS) and interleukin-1 $\beta$ (IL-1ß̣) were from Eurobio (Les Ulis, France). Fluo-4 AM and Fura-2 AM were from Molecular Probes (Leiden, Netherlands). Somatostatin-14 
and $\left[\operatorname{Tyr}^{0}, \mathrm{D}-\operatorname{Trp}^{8}\right]$ somatostatin-14 were purchased from NeoMPs (Strasbourg, France). Pituitary adenylate cyclase-activating polypeptide (PACAP) was generously provided by Pr Alain Fournier (INRS, Pointe-Claire, Canada).

\section{Astrocyte culture}

Purified cultures of astrocytes were prepared as previously described [26]. Briefly, cerebral hemispheres from newborn Wistar rats were collected in DMEM/Ham-F12 (2:1, v/v) culture medium supplemented with 2 mM glutamine, $1 \%$ insulin, $5 \mathrm{mM}$ HEPES, $0.4 \%$ glucose and $1 \%$ of the antibiotic-antimycotic solution. The tissues were disaggregated mechanically with a syringue equipped with a 1-mm gauge needle, and filtered through a $100-\mu \mathrm{m}$ pore size mesh filter (Falcon, Becton Dickinson, Grenoble, France). Dissociated cells were resuspended in culture medium supplemented with $10 \%$ heat-inactivated FBS and seeded in $150-\mathrm{cm}^{2}$ culture flasks (Falcon) at the density of $2 \times 10^{7}$ cells per flask. The cells were incubated at $37^{\circ} \mathrm{C}$ in a humidified atmosphere $\left(5 \% \mathrm{CO}_{2}\right)$ and the medium was changed twice a week. When cultures were confluent, the flasks were gently shaken on an orbital shaker at $250 \mathrm{rpm}$ for $2 \mathrm{~h}$. Dislodged cells were discarded and a second step of purification was performed at $250 \mathrm{rpm}$ for 14-16 h. Remaining adhesive cells were collected by trypsination, centrifuged $(100 \mathrm{~g}, 10 \mathrm{~min})$ and plated in $150-\mathrm{cm}^{2}$ flasks. Suspended astrocytes were harvested and seeded in 96-well plates (for calcium studies), 24-well plates (for binding studies), 14-mm glass coverslips (for electrophysiological experiments and $\left[\mathrm{Ca}^{2+}\right]_{\mathrm{c}}$ measurements), 35-mm dishes (for measurement of PIP turnover) and in 60- $\mathrm{mm}$ dishes (for measurement of endozepine release). The purity of the cultures was assessed by GFAP immunostaining which showed that enriched cultures contained $>98 \%$ astrocytes [22].

\section{Binding studies}

Three $\mu \mathrm{g}$ of UII or $\left[\operatorname{Tyr}^{0}, \mathrm{D}-\operatorname{Trp}^{8}\right]$ somatostatin- 14 , in phosphate buffer $(0.375$ $\mathrm{mM}, \mathrm{pH}$ 7.4), were labeled with $0.5 \mathrm{mCi} \mathrm{Na}^{125} \mathrm{I}$ (Amersham Biosciences) by the lactoperoxidase method as previously described [25]. Mono-iodinated [ ${ }^{125}$ I]UII or $\left[{ }^{125} \mathrm{I}^{\mathrm{T}} \mathrm{Tyr}^{0}, \mathrm{D}-\operatorname{Trp}^{8}\right]$ somatostatin-14 used for the radioligand binding assays were 
purified by reversed-phase HPLC on an Adsorbosphere $\mathrm{C}_{18}$ column $(0.46 \mathrm{X} 25-\mathrm{cm}$, Alltech) using a linear gradient (25-65\% over $40 \mathrm{~min}$ ) of acetonitrile/trifluoro acetic acid $(99.9: 0.1, \mathrm{v} / \mathrm{v})$ at a flow rate of $1 \mathrm{~mL} / \mathrm{min}$, and stored at $4^{\circ} \mathrm{C}$. The specific radioactivity of each radioiodinated peptide was approximately $2000 \mathrm{Ci} / \mathrm{mmol}$.

Cultured astrocytes were rinsed three times with phosphate buffered saline (PBS), dried under a cold air stream and stored at $-80^{\circ} \mathrm{C}$ until binding experiments. Frozen cells were washed twice with assay buffer (50 mM Tris buffer, $1 \mathrm{mM} \mathrm{MnCl}$ and $0.5 \%$ BSA) and incubated at $22^{\circ} \mathrm{C}$ in the same buffer in the presence of radiolabeled peptide. At the end of the incubation, cells were washed three times with assay buffer, solubilized with $1 \%$ SDS and the radioactivity was counted in a gamma counter (LKB Wallac, Evry, France). For competition experiments, cells were incubated for $3 \mathrm{~h}$ with $\left[{ }^{125} \mathrm{I}\right]$ UII $(0.2 \mathrm{nM})$ or $\left[{ }^{125} \mathrm{I}_{-T y r}{ }^{0}, \mathrm{D}-\operatorname{Trp}^{8}\right]$ somatostatin-14 $(0.4 \mathrm{nM})$ in the presence of graded concentrations of unlabeled UII, URP or somatostatin-14. Non-specific binding was determined by addition of $1 \mu \mathrm{M}$ unlabeled UII or $\left[\operatorname{Tyr}^{0}, \mathrm{D}-\mathrm{Trp}^{8}\right]$ somatostatin-14.

\section{Measurement of cytosolic $\mathrm{Ca}^{2+}$ concentration}

Purified astrocytes were plated into 96-well plates at 30,000 cells/well or in 14$\mathrm{mm}$ glass coverslips in complete medium added with FBS (10\%). After 2 days in culture, astrocytes were rinsed twice with a modified Hank's balanced salt solution (HBSS) containing (in $\mathrm{mM}$ ): $135 \mathrm{NaCl} ; 5 \mathrm{KCl} ; 1 \mathrm{MgCl}_{2} ; 1 \mathrm{CaCl}_{2} ; 10$ HEPES, 3 glucose; 2.5 probenicid ( $\mathrm{pH} 7.4$ ). Cells were incubated at $37^{\circ} \mathrm{C}$ with $40 \mu \mathrm{L}$ of $2 \mu \mathrm{M}$ fluo-4 AM or Fura-2 AM dye containing 20\% pluronic acid for $40 \mathrm{~min}$ in a $5 \% \mathrm{CO}_{2}$ atmosphere. Cells were washed twice with modified HBSS, and the effects of graded concentrations of URP and UII on $\left[\mathrm{Ca}^{2+}\right]_{\mathrm{c}}$ were measured with a fluorometric imaging plate reader FlexStation II (Molecular Devices, Sunnyvale, CA). Agonist-induced changes in $\left[\mathrm{Ca}^{2+}\right]_{c}$ were also measured (fluorescence at $510 \mathrm{~nm}$ following excitation at $340 / 380 \mathrm{~nm}$ from a $300 \mathrm{~W}$ xenon lamp) in individual cells from a single visual field using an integrating CCD camera coupled to a Leica DMLFSA microscope. Cell calcium imaging and fluorescence quantification were carried-out using the Metafluor Imaging System (Molecular Devices, Sunnyvale, CA). 
Measurement of polyphosphoinositide metabolism

Two to five-day-old (2-5 DIV) cultured astrocytes were incubated at $37^{\circ} \mathrm{C}$ with $10 \mu \mathrm{Ci} / \mathrm{mL}$ myo- $\left[{ }^{3} \mathrm{H}\right]$ inositol in glucose-, insulin- and serum-free medium, for 80 to 120 minutes. The incubation was stopped by removing the medium and adding icecold $10 \%$ trichloroacetic acid. The cells were homogenized and centrifuged $(15,000$ $\left.\mathrm{rpm}, 4^{\circ} \mathrm{C}, 10 \mathrm{~min}\right)$. The pellet was washed with $500 \mu \mathrm{L}$ chilled water and $\left[{ }^{3} \mathrm{H}\right] \mathrm{PIP}$ were extracted with $500 \mu \mathrm{L}$ of chloroform/ethanol $(2: 1, \mathrm{v} / \mathrm{v})$. The radioactivity was counted in a beta counter (LKB 1217 Rack Beta, EG and G Wallac, Evry, France).

\section{Electrophysiological experiments}

Electrophysiological recordings were performed at room temperature $\left(22^{\circ} \mathrm{C}\right)$ on 2-4 DIV cultured astrocytes seeded on glass coverslips using the standard amphotericin B-perforated configuration of the patch-clamp technique. The patch pipettes were fabricated from $1.5-\mu \mathrm{m}$ (outer diameter) soft glass tubes on a two-step vertical pipette puller (List-Medical, L/M-3P-A, Darmstadt, Germany). Patch electrodes had a final resistance of 5-7 M . The internal pipette solution contained $130 \mathrm{mM} \mathrm{KMeSO}{ }_{4} ; 20 \mathrm{mM} \mathrm{KCl} ; 5 \mathrm{mM} \mathrm{MgCl}_{2} ; 1 \mathrm{mM}$ EGTA; $10 \mathrm{mM}$ HEPES (adjusted at $\mathrm{pH} 7.4$ with $\mathrm{KOH}$ ). Before each experiment, the medium was replaced by a bath solution: $145 \mathrm{mM} \mathrm{NaCl} ; 5.4 \mathrm{mM} \mathrm{KCl} ; 1.8 \mathrm{mM} \mathrm{CaCl}_{2} ; 0.8 \mathrm{mM} \mathrm{MgCl} 2 ; 10 \mathrm{mM}$ HEPES; $10 \mathrm{mM}$ glucose ( $\mathrm{pH} 7.4$ adjusted with $\mathrm{NaOH}$ ). Cells were transferred to the stage of an upright microscope (DMLFSA, Leica, Heidelberg, Germany). Voltage signals were recorded from an Axopatch 200A amplifier (Axon Instruments, Foster City, CA, USA) and filtered at $2 \mathrm{kHz}$ ( $3 \mathrm{db}$, four-pole, Low-pass Bessel filter). Cell input resistance was monitored by applying hyperpolarizing pulses $(2 \mathrm{pA}, 10 \mathrm{~ms}$, $0.125 \mathrm{~Hz}$ ) to the cell under study. Data acquisition and analysis were performed through a digidata 1200 interface using the pClamp 8 suite programs (Axon Instruments) and the Origin 4.1 analysis software (Microcal Software, Northampton, MA, USA). 
Measurement of endozepine release

5-DIV astrocytes were incubated for $60 \mathrm{~min}$ at $37^{\circ} \mathrm{C}$ with fresh serum-free medium in the absence or presence of test substances. Peptides contained in culture media were concentrated on Sep-Pak $\mathrm{C}_{18}$ cartridges (Waters, Saint-Quentin en Yvelines, France). Bound material was eluted with 50\% (v/v) acetonitrile/water containing $0.1 \%$ TFA $(\mathrm{v} / \mathrm{v})$ and dried by vacuum centrifugation (Speed Vac concentrator, Savant, Hicksville, NY, USA) until radioimmunoassay (RIA).

The concentrations of ODN-like immunoreactivity (ODN-LI) in the Sep-Pakprepurified samples were quantified by RIA using an antiserum raised against synthetic rat ODN [20]. The analog [Tyr $\left.{ }^{0}\right]-O D N$ was iodinated using the chloramine-T procedure and purified on a Sep-Pak $\mathrm{C}_{18}$ cartridge. The final dilution of the ODN antiserum was $1: 30,000$ and the total amount of tracer was $6,000 \mathrm{cpm} / \mathrm{tube}$. The antibody-bound ODN fraction was precipitated by addition of $100 \mu \mathrm{L}$ bovine $\gamma$ globulins $(1 \%, \mathrm{w} / \mathrm{w})$ and $2 \mathrm{~mL}$ polyethylene glycol $8000(20 \%, \mathrm{w} / \mathrm{v})$. After centrifugation, the pellet containing the bound fraction was counted in a gamma counter (LKB Wallac, Rockville, MI, USA).

\section{Plasmid construction, HEK transfection and BRET assay}

Human UT receptor (hUT) and protease-activated receptor 1 (PAR-1) in pCDNA3.1 were purchased from cDNA Ressources Center (Rolla, MO, USA). The ability of receptors to activate $G_{i / o}$ proteins was controlled by measuring BRET between $\mathrm{G}$ protein subunits. Thus, we used $\mathrm{G}_{\alpha}$-Rluc fusioned proteins, the Renilla reniformis luciferase (Rluc) fusioned to the $G$ protein $\alpha$ subunit $G_{\alpha_{0}}$ in the loop between helices $\alpha A$ and $\alpha B$ in the h- $\alpha$ domain [28], and the Venus tagged $G_{\gamma 2}$ subunit generously provided by Dr C. Galès (Inserm U858, Toulouse, France).

HEK-cells (HEK293) were grown in complete medium (DMEM supplemented with $10 \%$ (v/v) FBS, $4.5 \mathrm{~g} / \mathrm{L}$ glucose, $100 \mathrm{U} / \mathrm{mL}$ penicillin, $0.1 \mathrm{mg} / \mathrm{mL}$ streptomycin, and $1 \mathrm{mM}$ glutamine (Invitrogen). Transient transfections were performed with the indicated plasmids using lipofectamine 2000 following the manufacturer's protocol (Invitrogen). All constructs were verified by sequencing, and their expression in HEK293 cells was confirmed by BRET signals. 
For BRET experiments, $48 \mathrm{~h}$ after transfection, HEK293 cells were washed with PBS, and coelenterazine $h$ substrate (Promega, Charbonnières, France) was added at a final concentration of $5 \mu \mathrm{M}$ in the total volume of $30 \mu \mathrm{L} /$ well at $37^{\circ} \mathrm{C}$. For kinetic analysis, BRET readings were then performed immediately after coelenterazine addition. After BRET signal stabilization $(\approx 100 \mathrm{sec})$, the different ligands were injected by the Mithras LB 940 plate reader (Berthold Biotechnologies, Bad Wildbad, Germany). BRET signals were expressed in milliBRET units of BRET ratio as previously described [29].

\section{Cell proliferation}

To determine cell survival and proliferation, 2-DIV cultured astrocytes were grown in the complete culture medium supplemented with 10\% FBS. Cells were either incubated in the absence or presence of URP, UII, endothelin-1, PACAP or interleukin-1 $\beta$ (IL-1 $\beta$ ) for $24 \mathrm{~h}$ in the same complete medium (WST-1 assay, $2 \mathrm{~h}$ ) or rinsed in FBS-free medium and incubated after $24 \mathrm{~h}$ in the absence or presence of URP or UII for $48 \mathrm{~h}$ (cell counting). Astrocytes were rinsed three times in PBS $\left(37^{\circ} \mathrm{C}\right)$ and cell proliferation was quantified by fluorescence measurement with a FL600 microplate reader $(450 / 750 \mathrm{~nm})$ or by counting the cell number with an electronic cell counter (Z2, Beckman Coulter, Roissy, France).

\section{Data analysis}

To calculate the Hill coefficient $\left(n_{\mathrm{H}}\right)$, competition curves were first fitted to the Hill equation via a nonlinear regression using the computerized curve-fitting package GraphPad Prism version 4 for Windows (GraphPad Software, San Diego, CA, USA). The data were then re-fitted using equation for displacement of radioligand by competitors to one or two binding sites. A two-site curve-fitting model was retained when this model fitted the data significantly better than a one-site model, as determined by a $F$-test at a significance level of $p<0.05$. $\mathrm{IC}_{50}$ values derived from these latter fits were converted to apparent competition-receptor dissociation equilibrium constants $K_{1}$ for the very high affinity and $K_{2}$ for the high-affinity binding sites. For biological activities, values presented in the figures are means \pm S.E.M. 
Statistical significance of differences was determined by using the one-way ANOVA followed by a Dunnett's post hoc test or the non-parametric Friedman's test.

\section{Results}

Binding characteristics of URP on cultured rat astrocytes

Competition experiments performed with $\left[{ }^{125} \mathrm{I}\right] \mathrm{UII}(0.2 \mathrm{nM})$ as a tracer and unlabelled UII $(1 \mathrm{pM}-1 \mu \mathrm{M})$ generated a biphasic curve with a Hill coefficient of $0.81 \pm 0.06$ (Fig. 2A). In contrast, graded concentrations of unlabeled URP (1 pM-1 $\mu \mathrm{M})$ generated a monophasic displacement curve with a Hill coefficient close to 1 . Statistical analysis of the competition experiments using the $F$-test showed that data best fitted with a two-site model $(p<0.05)$ and the calculated dissociation constants for the high- $\left(K_{1}\right)$ and low-affinity $\left(K_{2}\right)$ sites were $0.31 \pm 0.12$ and $32.9 \pm 18.7 \mathrm{nM}$ for UII and with a one-site model $(p<0.05)$ yielding a dissociation constant for a highaffinity $(K)$ site of $1.62 \pm 0.74 \mathrm{nM}$, for URP (Fig. $2 \mathrm{~A}$, inset). We thus tested the ability of URP and UII, which exhibit sequence similarities with somatostatin in their cyclic portion, to displace the binding of the somatostatin analog $\left[{ }^{125} \mathrm{I}-\mathrm{Tyr}^{0}, \mathrm{D}-\right.$ $\operatorname{Trp}^{8}$ ]somatostatin-14 (0.4 nM). Graded concentrations of unlabeled URP (10 pM-10 $\mu \mathrm{M})$ showed a biphasic competition curve with a Hill coefficient of $0.32 \pm 0.09$ (inset) and dissociation constants for high $\left(K_{1}\right)$ - and low $\left(K_{2}\right)$-affinity sites of $9.16 \pm 5.32 \mathrm{nM}$ and $4.42 \pm 1.72 \mu \mathrm{M}$, respectively. In contrast, UII $(3 \mathrm{nM}-30 \mu \mathrm{M})$ failed to displace

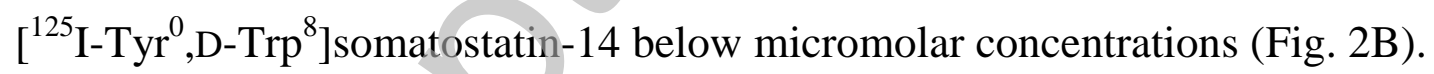

Similar effects of URP and UII on resting membrane potential and endozepine release from cultured rat astrocytes

To investigate the action of URP and UII on the electrical activity of cultured astrocytes, amphotericin-perforated patch-clamp recordings were performed. Under current-clamp conditions (holding potential at $-52.12 \pm 3.08 \mathrm{mV} ; \mathrm{n}=32$ ), focal application of URP (Fig. 3A, upper; $100 \mathrm{nM} ; 2 \mathrm{~min}$ ) or UII (Fig. 3A, lower; $100 \mathrm{nM} ; 2$ min) elicited a membrane depolarization in $69 \%$ of astrocytes (20/29) accompanied by 
a decrease of the input resistance. The majority of responding astrocytes remained in a depolarized state during the washout period (Fig. 3A). The amplitudes of membrane depolarization induced by URP at concentrations of $10 \mathrm{nM}(9.6 \pm 2.6 \mathrm{mV}, \mathrm{n}=5)$ and $100 \mathrm{nM}(16.6 \pm 4.3 \mathrm{mV}, \mathrm{n}=8)$ were very similar to those evoked by UII (10 nM, $9 \pm 4 \mathrm{mV}, \mathrm{n}=3 ; 100 \mathrm{nM}, 15.5 \pm 2.8 \mathrm{mV}, \mathrm{n}=12$, Fig. 3B).

Graded concentrations of URP $(1 \mathrm{pM}-10 \mu \mathrm{M}, 1 \mathrm{~h})$ induced a dose-related increase in the release of ODN-LI with an $\mathrm{EC}_{50}$ value of $3.95 \pm 1.52 \mathrm{nM}$ and a maximum effect at a concentration of $1 \mu \mathrm{M}$ (data not shown). Incubation of cells with $0.1 \mathrm{nM}, 10 \mathrm{nM}$ and $1 \mu \mathrm{M}$ URP or UII provoked a concentration-dependent increase in ODN-LI release, non sigificantly different between URP and UH (Fig. 3C).

Similar mechanism of URP and UII on $\left[\mathrm{Ca}^{2+}\right]_{c}$ mobilization in cultured rat astrocytes

URP and UII $\left(0.1 \mu \mathrm{M}\right.$, each) induced a rapid $\left[\mathrm{Ca}^{2+}\right]_{\mathrm{c}}$ increase (peak) followed by a sustained response (plateau) [22]. Preincubation of astrocytes with the $\mathrm{G}_{\mathrm{i} / \mathrm{o}}$ protein inhibitor pertussis toxin (PTX, $0.2 \mu \mathrm{g} / \mathrm{mL}, 18 \mathrm{~h}$ ) did not affect the $\mathrm{Ca}^{2+}$ responses induced by both peptides (Fig. 4A). In contrast, the URP- and UII-induced $\mathrm{Ca}^{2+}$ mobilizations were completely blocked by the PLC inhibitor U73122 (10 $\mu \mathrm{M}, 20 \mathrm{~min})$ and were strongly reduced by the $\mathrm{IP}_{3}$-induced $\mathrm{Ca}^{2+}$ release and store-operated $\mathrm{Ca}^{2+}$ channels blocker 2-APB ( $50 \mu \mathrm{M}, 20 \mathrm{~min}$ ), by 83 and 80\%, respectively (Fig. 4B, C). In order to gain insight into the $\mathrm{Ca}^{2+}$ pools recruited by UII and URP, $\left[\mathrm{Ca}^{2+}\right]_{\mathrm{c}}$ were measured in the absence or presence of the extracellular $\mathrm{Ca}^{2+}$ chelator EGTA $(1 \mathrm{mM}$, $20 \mathrm{~min}$ ). Peak responses were partially attenuated by 53\% (URP) and 58\% (UII) and plateau phases were totally blocked in the presence of both peptides (Fig. 4D). The $\left[\mathrm{Ca}^{2+}\right]_{\mathrm{c}}$ increase evoked by UII and URP was also suppressed in the presence of the voltage-dependent T-type $\mathrm{Ca}^{2+}$ channel blocker mibefradil ( $1 \mu \mathrm{M}$, Fig. 4E, $\left.20 \mathrm{~min}\right)$, whereas the specific $\mathrm{L}$ - and $\mathrm{N}$-type $\mathrm{Ca}^{2+}$ channel blockers, nifedipine and $\omega$-conotoxin GVIA ( $1 \mu \mathrm{M}$, each, $20 \mathrm{~min}$ ), respectively, did not significantly affect the peptideevoked elevation of $\left[\mathrm{Ca}^{2+}\right]_{\mathrm{c}}$ in astrocytes (Fig. 4F, G). 
Divergent actions of URP and UII on $\left[\mathrm{Ca}^{2+}\right]_{\mathrm{c}}$ mobilization and PIP turnover in cultured rat astrocytes

As shown in Fig. 5A, exposure of astrocytes to increasing concentrations of URP and UII ( $1 \mathrm{pM}-10 \mu \mathrm{M}$, each) provoked a robust and sustained increase in $\left[\mathrm{Ca}^{2+}\right]_{\mathrm{c}}$, followed by a plateau phase. The dose-response study of the effects of URP and UII on $\left[\mathrm{Ca}^{2+}\right]_{\mathrm{c}}$ mobilization revealed that URP and UII induced a mono- and biphasic dosedependent $\left[\mathrm{Ca}^{2+}\right]_{\mathrm{c}}$ increase (Fig. 5A). The maximum stimulations (URP, 157\%; UII, $151 \%$ ) were obtained at $1 \mu \mathrm{M}$ for both peptides. The peptide-induced $\mathrm{Ca}^{2+}$ response were also investigated at a single astrocyte level using a digital imaging system. Application of $0.1 \mu \mathrm{M}$ URP resulted in a rapid and transient increase in $\left[\mathrm{Ca}^{2+}\right]_{\mathrm{c}}$ levels $(136.9 \pm 3.5 \%)$, in a subset of 59\% astrocytes (16/24, Fig. 5B). Surprisingly, the UIIevoked $\left[\mathrm{Ca}^{2+}\right]_{\mathrm{c}}$ response was characterized by a rapid increase followed by a sustained or developing increase of the $\left[\mathrm{Ca}^{2+}\right]_{\mathrm{c}}$ level, reaching $137.1 \pm 5.2 \%$ stimulation after $400 \mathrm{sec}$ of recording, in $70 \%$ of cell (21/26, Fig. 5C).

As observed on $\mathrm{Ca}^{2+}$ levels, exposure of astrocytes to graded concentrations of URP $(1 \mathrm{pM}-1 \mu \mathrm{M})$ induced a dose-dependent increase in $\left[{ }^{3} \mathrm{H}\right]$ inositol incorporation into PIP with an $\mathrm{EC}_{50}$ value of $2.19 \pm 1.42 \mathrm{nM}$ (Fig. 6A). In contrast, UII (1 pM-1 $\mu \mathrm{M})$ evoked a biphasic dose-dependent stimulation of PIP turnover yielding an $\mathrm{EC}^{1}{ }_{50}$ of $9.1 \pm 4.6 \mathrm{pM}$ and an $\mathrm{EC}^{2}{ }_{50}$ of $11.0 \pm 4.6 \mathrm{nM}$ (Fig. 6A). The amplitude of the stimulatory effect of URP (10 nM; $141.5 \pm 8.6 \%$ of control) on PIP metabolism was not significantly different from that obtained with UII $(10 \mathrm{nM} ; 154.4 \pm 12.8 \%$ of control). Co-application of URP (10 nM) with a saturating concentration of UII (10 $\mathrm{nM})$ induced an increase in $\left.{ }^{3} \mathrm{H}\right]$ inositol incorporation into PIP $(160 \pm 12.8 \%)$ that did not significantly exceed the effect of each peptide administered alone (Fig. 6B). In same sets of experiment, PTX $(0.2 \mu \mathrm{g} / \mathrm{mL} ; 18 \mathrm{~h})$ significantly decreased the incorporation of $\left[{ }^{3} \mathrm{H}\right]$ inositol into PIP induced by UII $(100 \mathrm{nM},-45 \%)$ but failed to significantly affect the stimulatory effect of URP (100 nM, $-26 \%)$ (Fig. 6C). 
Specific activation of $G_{0}$ protein by UII and URP in cells expressing recombinant hUT

To control whether UT might be coupled to $\mathrm{G}_{\mathrm{i} / \mathrm{o}}$ proteins in the presence of UII, but also URP, we used the BRET approach to directly monitor $\mathrm{G}_{\alpha o}$ protein activation in living cells [30, 31]. This assay is based on the $\mathrm{G}$ protein complex conformational change and the dissociation of the $G_{\alpha 0}$ fused with the energy donnor Rluc, from the $G_{\gamma 2}$ fused with the energy acceptor YFP upon receptor activation. These fusioned G protein subunits were shown to be correctly expressed and to allow an efficient coupling of receptors to their effectors (data not shown). In HEK293 cells coexpressing $\mathrm{G}_{\alpha 0}$-Rluc, $\mathrm{G}_{\gamma_{2}}$-YFP and either recombinant hUT (HEK293-hUT) or PAR-1 (HEK293-PAR-1), a significant BRET signal was detected compared to cells expressing only $\mathrm{G}_{\alpha 0}$. When HEK293-hUT cells were treated with PBS or Thrombin (Thr, $50 \mathrm{U} / \mathrm{mL}$ ), the BRET signal is not modified (Fig. 7A). In contrast, kinetic analysis showed that UII and URP $(10 \mu \mathrm{M}$, each) injection provoked BRET signal decrease between $G_{\alpha 0}$ and $G_{\gamma_{2}}$ subunits, which occurred rapidly and persisted for more than one minute (Fig. 7B). In order to control the specificity of the UT- $\mathrm{G}_{\mathrm{o}}$ coupling, BRET signal was measured on HEK293-PAR-1 in the presence of Thr, UII and URP. In these cells, Thr induced BRET decrease whereas URP and UII failed to activate G protein dissociation (Fig. 7C).

\section{Effect of URP and UII on cell yiability/proliferation in cultured rat astrocytes}

2-DIV cells (non synchronized) were cultured in complete medium additionned with FBS and then incubated in a FBS-free medium containing URP or UII $(10 \mathrm{nM}$, each). Cell viability was measured $24 \mathrm{~h}$ later by using WST-1 assay, allowing detection of mitochondrial activity related to the number of viable cells. Fig. 8A showed that URP failed to affect the cell viability whereas UII stimulated by $132.7 \%$ the astrocyte growth. PACAP $(10 \mathrm{nM})$, interleukin-1 (IL-1 $\beta, 10 \mathrm{ng} / \mathrm{mL})$ and endothelin-1 (ET-1, $10 \mathrm{nM})$ were also tested as positive controls and gave rise respectively to $126.3,169.3$ and $171.1 \%$ increase (Fig. 8A). The dose-response effects of URP and UII on cell growth were also investigated in non-synchronized (WST-1, Fig. 8B) and synchronized (18 h of harvesting, counting, Fig. 8C) astrocytes. A $24 \mathrm{~h}$ 
(Fig. 8B) or 48 h-treatment (Fig. 8C) with graded concentrations of URP failed to significantly modify the rate of cell growth. In contrast, UII induced a dose-dependent cell growth, yielding an $\mathrm{EC}_{50}$ value of $2.37 \pm 0.02 \mathrm{nM}$, and a maximum stimulatory effect of $132.9 \pm 7.0 \%$ at $1 \mu \mathrm{M}$ (Fig. 8B) in non-synchronized cultures, and evoked a significant cell number increase $(120.1 \pm 2.9 \%)$ at $0.1 \mu \mathrm{M}$ in synchronized conditions (Fig. 8C).

\section{Discussion}

Although the cardiovascular effects of the urotensinergic system are now well characterized, little is known concerning the roles of UII and URP in the CNS. Immunohistochemical studies have shown the presence, in the rat brain, of UT-like immunoreactivity in GFAP-positive cells within the brainstem, hypothalamus and thalamus [23]. In agreement with these observations, we have recently demonstrated that rat cortical astrocytes express UT mRNA, contain the UT protein, and exhibit very high- and high-affinity UII binding sites [22]. In these cells, UII specifically activates a PLC/PIP/Ca ${ }^{2+}$ transduction pathway, via both PTX-sensitive and -insensitive G proteins [22]. The identification of a UII paralog, URP, which apparently exhibits the same pharmacological characteristics as UII [3], raises the question as to whether URP functions as a UII backup in the brain. In the present study, we have looked for the existence of URP binding sites in cultured rat astrocytes and we have compared the mechanisms of action of URP and UII on astroglial cell activity.

Competition experiments revealed that URP could displace $\left[{ }^{125} \mathrm{I}\right] \mathrm{UII}$ at nanomolar concentrations ( $K=1.62 \mathrm{nM}$ ) with a Hill coefficient close to 1 , suggesting the existence of an homogeneous population of URP binding sites in astrocytes. However, the occurrence of two affinity binding sites for UII has been previously described in CHO cells expressing recombinant human UT [27] and in rat cortical astrocytes [22]. In our model, URP is five fold less potent in competing for the very high affinity UII binding site and twenty fold more potent in displacing UII from the high-affinity site, indicating that UII and URP exhibit different binding characteristics in astrocytes. Interestingly, URP and the C-terminal octapeptide of human UII, UII ${ }_{4-11}$, 
were 10 times more potent than human UII in competing with [ $\left.{ }^{125} \mathrm{I}\right] \mathrm{UII}$ at recombinant UT [3, 32], suggesting that the N-terminal segment of UII decreases the affinity of the peptide for its receptor. It has previously been shown that cultured rat astrocytes express UT mRNA and that UT-like immunoreactivity is located at the plasma membrane of astroglial cells $[22,23]$. Thus, the present study suggests that the high affinity site bound by URP actually correspond to UT. The cyclic hexapeptide core of UII and URP exhibits substantial similarities with the biologically active region of somatostatin-14 ([33, 34]; Fig. 1) and UT shares sequence identity with somatostatin receptors (sst) [35]. In spite of these relatively high degree of sequence homologies, UII exhibits very low affinity for somatostatin receptors (sst1, sst2 and sst4) either transfected in cell lines [36] or naturally expressed in astrocytes [20, 22, 37]. The present data show that URP could displace $\left[{ }^{125}{ }^{2}-\mathrm{Tyr}^{0}, \mathrm{D}-\mathrm{Trp}^{8}\right]$ somatostatin-14 binding to both high- and low-affinity sites. This observation indicates that, unlike rat UII that selectively binds to UT, URP can interact with both UT and somatostatin receptors expressed in rat cortical astrocytes. In agreement with these data, a recent comparative genomic study has established the existence of a close evolutionary relationship between urotensinergic and somatostatinergic gene families, particularly between URP and somatostatin-14 peptides [5]. Moreover, it has recently been demonstrated that high concentration of URP stimulates $\left[\mathrm{Ca}^{2+}\right]_{\mathrm{c}}$ levels and proliferation of recombinant sst-2 expressing CHO cells [38]. Together, it is suggested that shorter urotensinergic peptides in their N-terminal sequence (Fig. 1; human UII and URP) were more potent than longer UII (rat UII) in competing for the high affinity UII binding site UT, and also acquired the ability to bind sst.

Astrocytes have long been considered as non-excitable support of neuronal cells in the brain. It is now well established that astroglial cells express functional channels and receptors enable to sense synaptic transmission [39]. In addition, astrocytes participate in neuronal functioning not only via feeding and structural support, but also through release of gliotransmitters such as glutamate, D-serine, ATP, cytokines or endozepines [16]. Application of URP or UII in the vicinity of astrocytes in culture induced a slow in onset membrane depolarization accompanied by a decrease of the input resistance. It has also been demonstated that UII depolarizes nervous cells on 
brainstem cholinergic neurons and evokes a membrane conductance decrease [40, 41]. Astrocytes in culture or acutely dissociated from different brain regions, may express various ion channels including both $\mathrm{T}$ - and L-type $\mathrm{Ca}^{2+}$ channels, different $\mathrm{K}^{+}$ channels and also store-operated $\mathrm{Ca}^{2+}$ channels [42]. Thus, URP as well as UII may inhibit $\mathrm{K}^{+}$channel activity and/or stimulate voltage-activated $\mathrm{Ca}^{2+}$ channel opening either directly or upon depolarizing stimulus. Astrocytes are able to synthesize, store and release endozepines via $\mathrm{Ca}^{2+}$-dependent and/or cAMP/PKA-dependent ways [19]. It is likely that depolarization of glial cells evoked by both peptides subserves neurotransmitter secretion, transcription or proliferation.

It is now clearly established that activation of UII receptor expressed in native cells or in transfected-cell lines, is associated with an increase in PIP turnover causing mobilization of $\mathrm{Ca}^{2+}$ from intracellular stores [43, 44]. Exposure of astrocytes to URP and UII was associated with $\left[\mathrm{Ca}^{2+}\right]$ mobilization, i.e. a rapid peak response followed by a plateau phase. Peptide-induced $\left[\mathrm{Ca}^{2+}\right]_{\mathrm{c}}$ increase was PLC-dependent (U73122 sensitive) and resulted from activation of $\mathrm{IP}_{3}$-receptor pools (2-APB sensitive). These data are in a good agreement with previous observations made in sartorius muscle, vascular tissues, or in rabdomyosarcoma cell lines [44-46]. Since PLC-inducing $\mathrm{Ca}^{2+}$ mobilization is typically mediated via $\mathrm{G}_{\mathrm{q}}$ and/or $\mathrm{G}_{\mathrm{i} / \mathrm{o}}$ protein, and UII receptor sites might be linked to $\mathrm{G}_{\mathrm{i} / \mathrm{o}}$ protein types $[3,22,46]$, the ability of URP versus UII was tested in PTX-pretreated astrocytes. PTX, which catalyses ADP-ribosylation of $\mathrm{G}_{\mathrm{i} / \mathrm{o}^{-}}$ type $\mathrm{G}$ proteins and consequently inactivates their transduction mechanisms [47], did not affect the $\mathrm{Ca}^{2+}$ response evoked by both peptides, indicating that URP and UII tested at micromolar range activate a receptor coupled to a $\mathrm{PLC} / \mathrm{IP}_{3} / \mathrm{Ca}^{2+}$ pathway in a $\mathrm{G}_{\mathrm{i} / \mathrm{o}}$ independent manner. The involvement of the extracellular $\mathrm{Ca}^{2+}$ pool was also tested by means of experiments in the presence of EGTA, and voltage-gated $\mathrm{Ca}^{2+}$ channel blockers. It is thus demonstrated that extracellular chelation of $\mathrm{Ca}^{2+}$ attenuated the peak, and totally blocked the plateau responses, indicating that the transient $\mathrm{Ca}^{2+}$ peak is partially attributable to $\mathrm{Ca}^{2+}$ release from the sarcoplasmic reticulum, whereas the sustained plateau phase is due to $\mathrm{Ca}^{2+}$ influx. Surprisingly, $\left[\mathrm{Ca}^{2+}\right]_{\mathrm{c}}$ increase induced by both peptides was completely abolished by the specific inhibition of the T-type calcium channel (mibefradil) and appeared insensitive to both blockage of L- and N- 
type channels by nifedipine and $\omega$-conotoxine GVIA, respectively. These observations suggest that high level of UT activation leads to the recruitement of both extra- and intracellular $\mathrm{Ca}^{2+}$ pools and to a cross-talk between $\mathrm{IP}_{3}$ receptors and at least voltagedependent T-type channels. T-type channels are represented by three different $\mathrm{Ca}^{2+}$ channels, i.e. $\alpha 1 \mathrm{G}$ or Cav3.1, $\alpha 1 \mathrm{H}$ or Cav3.2 and $\alpha 1 \mathrm{I}$ or Cav3.3 [48] and mRNA transcripts encoding the functional $\alpha 1 \mathrm{G}$ T-type subunit channels have been found in cultured astrocytes [49]. An interesting property of T-type $\mathrm{Ca}^{2+}$ channels is their ability to sustain a continuous $\mathrm{Ca}^{2+}$ influx in glia at rest by a window current mechanism [50]. Interestingly, changes in membrane potential and intracellular $\mathrm{Ca}^{2+}$ may affect Gqprotein coupled $\mathrm{IP}_{3}$ production itself $[51,52]$. The components of the basic $\mathrm{G}_{\mathrm{q}} \mathrm{PCR} / \mathrm{IP}_{3}$ production pathway would be located in or associated with the plasma membrane, making them potentially susceptible to changes in membrane potential lipid in the inner leaflet of the plasma membrane [53]. These observations may unveil a similar UT- $\mathrm{G}_{\mathrm{q}}$ associated mechanism in astrocytes, where blockage of T-type $\mathrm{Ca}^{2+}$ channels may hyperpolarize astrocytes and inhibit $\mathrm{IP}_{3}$-induced $\mathrm{Ca}^{2+}$ release.

The dose-response curves of URP and UII on $\left[\mathrm{Ca}^{2+}\right]_{\mathrm{c}}$ show mono- and bi-phasic profiles, respectively. The agonist potency of URP $\left(\mathrm{EC}_{50} \sim 0.7 \mathrm{nM}\right)$ is similar to that one of the two sites of UII ( $\left.\mathrm{EC}_{50} \sim 0.7 \mathrm{nM}\right)$, and in close agreement with the binding characteristic at the common high affinity sites of URP and UII, positively coupled to a PLC-G $\mathrm{G}_{\mathrm{q}}$ protein pathway. It thus appears that the very high affinity binding site of UII, is not activated by URP and is functionally coupled to $\left[\mathrm{Ca}^{2+}\right]_{\mathrm{c}}$. Single-cell digital imaging techniques demonstratred that a majority of cells responded to URP and UII, even if the cell-cell variations in shape and amplitude can be observed. More surprisingly, URP $(0.1 \mu \mathrm{M})$ evoked a transient and reversible increase in $\left[\mathrm{Ca}^{2+}\right]_{\mathrm{c}}$ whereas a single UII $(0.1 \mu \mathrm{M})$ infusion induced a $\mathrm{Ca}^{2+}$ reponse that remained stable during more than $400 \mathrm{sec}$ of recording. This last effect may be attributable to the slow dissociation rate of UII, as already described for rat and human UII on UT-transfected cells, skeletal muscle myoblasts and astrocytes [22, 27, 46, 54]. Thus, the slow dissociation might be specific of UII and would likely accounts for the sustained and washout-resistant contractile responses induced by UII on primate arteries and $\left[\mathrm{Ca}^{2+}\right]_{\mathrm{c}}$ increase in rat cortical astrocytes. 
As observed for $\mathrm{Ca}^{2+}$ responses, $\left[{ }^{3} \mathrm{H}\right]$ inositol incorporation in PIP shows monoand biphasic profiles for URP and UII, respectively. Thus, URP and UII produced a concentration-dependent increase of $\left[\mathrm{Ca}^{2+}\right]_{\mathrm{c}}$ consistent with a $U \mathrm{UT}^{-} \mathrm{G}_{\mathrm{q}}$ coupling to PLC and $\mathrm{IP}_{3}$ formation-inducing $\mathrm{Ca}^{2+}$ release from intracellular stores. The percentage increase of PIP metabolism produced by a concomitant administration of URP and UII at their maximum effective concentrations was not significantly different from the effects of both peptides individually tested, indicating that this pathway might be common to the both peptides.

Here, we observed that the binding and the stimulatory effect of URP on the PIP metabolism were not significantly affected by a pre-treatment with PTX whereas half of the UII-induced PIP formation was blocked by PTX. This observation indicates that URP would not be promiscuously linked to the $\mathrm{G}_{\mathrm{i} / \mathrm{o}}$ PTX-sensitive binding site in astrocytes. In order to clarify a possible URP and UII-induced UT coupling to $\mathrm{G}_{\mathrm{i} / \mathrm{o}}$ proteins, kinetic BRET signal changes were measured in HEK293 cells transiently cotransfected with $\mathrm{G}_{\alpha 0}$-Rluc and $\mathrm{G}_{\gamma 2}$-YFP, and with either hUT or the control receptor PAR-1. In these conditions, UII but also URP provoked a fast decrease of BRET exclusively in cells expressing hUT, resulting from UT- $G_{o}$ activation and $G_{00}-G_{\gamma 2}$ dissociation. These data indicate that in a recombinant system, both UII and URP are able to activate a UT- $\mathrm{G}_{\mathrm{i} / \mathrm{o}}$ PTX sensitive coupling system.

In astrocytes, PTX partially inhibited the effect of UII, and in a very less extent of URP, on PIP whereas it failed to block the UII/URP-evoked $\mathrm{Ca}^{2+}$ response, suggesting the existence of a specific PTX-insensitive UT-G $\mathrm{G}_{\mathrm{q}}-\mathrm{PLC}-\mathrm{IP}_{3}-\mathrm{Ca}^{2+}$ preferential coupling, and a PTX-sensitive UT- $\mathrm{G}_{\mathrm{i} / \mathrm{o}} \mathrm{PIP}$ pathway more specific to UII. These two coincident cascades likely converge to an increase of the $\left[{ }^{3} \mathrm{H}\right]$ inositol incorporation into the PIP. Indeed, the stimulatory effect of UII and URP on the PIP turnover can be ascribed to $i$ ) the activation of the $\mathrm{PIP}_{2}$ hydrolysis into diacylglycerol and $\mathrm{IP}_{3}$ by PLC, culminating in the release of calcium from internal stores, and $i i$ ) the production of PIP, $\mathrm{PIP}_{2}$, and $\mathrm{PIP}_{3}$ upon the activation of PI-kinases in a $\mathrm{Ca}^{2+}$ independent manner. In particular, PIP synthesized by phosphatidylinositol-3 kinase (PI3K), are known to play a critical role in cell survival by membrane recruitment and activation of Akt/PKB kinase [55]. Since the PI3K has recently been shown to be 
involved in the UII-induced natriuretic peptide release from rat atria [56] and the MAPK pathway appeared clearly implicated in several UII processes including vascular and airway smooth muscle cell proliferation and migration, fibroblast proliferation or cardiomyocyte hypertrophy [57], we hypothesize that a UT- $\mathrm{G}_{\mathrm{i} / \mathrm{o}} \mathrm{PI} 3 \mathrm{~K}$ PTX sensitive pathway mainly activated by UII, and in a less extent by URP, might thus be involved in $\mathrm{Ca}^{2+}$-independent astrocyte activities.

Pathological processes in the brain are usually accompagnied by a significant astrocyte proliferation referred as to astrogliosis. Here, we demonstrated that UII, but not URP, significantly stimulated rat cortical astrocyte proliferation. Numerous studies have demonstrated that vasoactive peptides or interleukins play important roles in astrogliosis [58]. Thus, we demonstrated that in the same set of experiments, PACAP and ET-1 tested at the same concentration than URP and UII, as well as IL1- $\beta$, also markedly increase cell growth. Moreover, graded concentrations of URP and UII were tested on either non synchronized or synchronized cells, and the data demonstrate the existence of a UII-specific dose-dependent increase of cell viability. A similar activity for UII has already been observed on rat vascular smooth muscle cells [11], on human endothelial cells [59], and on UT transfected CHO cells [10]. Considering that URP has been shown to activate porcine sst2 [36], we proposed that the absence of mitogenic role of URP would be linked to its ability to bind sst expressed by astrocytes, as sst2 $[37,20]$. It is conceivable that concomitant $U T-G_{q}$ and $s s t 2-G_{i}$ recuitements by URP may $i$ ) also lead to $\left[\mathrm{Ca}^{2+}\right]_{\mathrm{c}}$ increase and/or ii) antagonize some specific very high-affinity UII/UT-mediating transduction pathways involved in cell proliferation.

In conclusion, the present study has demonstrated for the first time that URP and UII activate functional receptors in native rat cortical astrocytes, exhibiting similar and distinct ways of action. URP and UII bind a high affinity site that exhibits the pharmacological characteristics of UT, mediating cell depolarization, endozepine release and PLC-dependent $\mathrm{Ca}^{2+}$ mobilization through intra-( $\mathrm{IP}_{3}$ receptor) and extracellular (T-type $\mathrm{Ca}^{2+}$ channels) pools (Fig. 9). $\mathrm{Ca}^{2+}$ entry though T-type channels appears essential for $\mathrm{IP}_{3}$-induced $\mathrm{Ca}^{2+}$ increase whereas $\mathrm{Ca}^{2+}$ release from intracellular stores induces $\mathrm{Ca}^{2+}$ release. In addition, UII, and in a less extent URP, are able 
to activate a higher affinity site coupled to a PTX-sensitive G protein, that would mediate an hypothetical PI3K activation, relaying an important physiological astrocyte behavior, i.e. cell proliferation (Fig. 9). Finally, URP, but not UII, may bind sst expressed in rat astrocytes whose activation would mimick the UT-Ca ${ }^{2+}$ coupling and/or counteract the mitogenic role of UT (Fig. 9). These data provide the first understanding of the involvement of the two vasoactive peptides UII and URP in nerve cell activity, stressing the specific role of UII in the (patho)physiology of astrocytes.

\section{Acknowledgements}

We gratefully acknowledge Mr Sébastien Arthaud, Mrs Huguette Lemonnier and Mr Gérard Cauchois for skillful technical assistance. We thank Laetitia Comps-Agrar, Claire Vol, and Mohammed Akli Ayoub for their technical and scientific assistance, and the Pharmacology Screening-Interactome Platform facilities of the Institut Fédératif de Recherche 3 of Montpellier (France). This work was supported by Inserm (U982), the European Institute for Peptide Research (IFRMP 23), the Lille-AmiensRouen-Caen Neuroscience network and the Conseil Régional de Haute-Normandie. M.D. was recipient of a fellowship from the Lille-Amiens-Rouen-Caen Neuroscience network and the Conseil Régional de Haute-Normandie. H.V. was recipient of the De Bétancourt-Perronet award for scientific cooperation between France and Spain. We thank Pr Alain Fournier (INRS, Pointe-Claire, Canada), who has generously provided PACAP. 


\section{References}

1 Pearson, D., Shively, J. E., Clark, B. R., Geschwind, I. I., Barkley, M., Nishioka, R. S. and Bern, H. A. (1980) Urotensin II: a somatostatin-like peptide in the caudal neurosecretory system of fishes. Proc. Natl. Acad. Sci. USA 77, 5021-5024

2 Douglas, S. A. and Ohlstein, E. H. (2000) Human urotensin-II, the most potent mammalian vasoconstrictor identified to date, as a therapeutic target for the management of cardiovascular disease. Trends Cardiovasc. Med. 10, 229-237

3 Sugo, T., Murakami, Y., Shimomura, Y., Harada, M., Abe, M., Ishibashi, Y., Kitada, C., Miyajima, N., Suzuki, N., Mori, M. and Fujino, M. (2003) Identification of urotensin II-related peptide as the urotensin II-immunoreactive molecule in the rat brain. Biochem. Biophys. Res. Commun. 310, 860-868

4 Leprince, J., Chatenet, D., Dubessy, C., Fournier, A., Pfeiffer, B., Scalbert, E., Renard, P., Pacaud, P., Oulyadi, H., Ségalas-Milazzo, I., Guilhaudis, L., Davoust, D., Tonon, M. C. and Vaudry, H. (2008) Structure-activity relationships of urotensin II and URP. Peptides 29, 658-673

5 Tostivint, H., Joly, L., Lihrmann, I., Parmentier, C., Lebon, A., Morisson, M., Calas, A., Ekker, M. and Vaudry, H. (2006) Comparative genomics provides evidence for close evolutionary relationships between the urotensin II and somatostatin gene families. Proc. Natl. Acad. Sci. USA 103, 2237-2242

6 Coulouarn, Y., Fernex, C., Jégouu, S., Henderson, C. E., Vaudry, H. and Lihrmann, I. (2001) Specific expression of the urotensin II gene in sacral motoneurons of developing rat spinal cord. Mech. Dev. 101, 187-190

7 Dun, S. L., Brailoiu, G. C., Yang, J., Chang, J. K. and Dun, N. J. (2001) Urotensin II-immunoreactivity in the brainstem and spinal cord of the rat. Neurosci. Lett. 305, 9-12

Sugo, T. and Mori M. (2008) Another ligand fishing for G protein-coupled receprtor 14. Discovery of urotensin II-related peptide in the rat brain. Peptides 29, 809-812

9 Ames, R. S., Sarau, H. M., Chambers, J. K., Willette, R. N., Aiyar, N. V., Romanic, A. M., Louden, C. S., Foley, J. J., Sauermelch, C. F., Coatney, R. W., Ao, Z., Disa, J., Holmes, S. D., Stadel, J. M., Martin, J. D., Liu, W. S., Glover, G. I., Wilson, S., McNulty, D. E., Ellis, C. E., Elshourbagy, N. A., Shabon, U., Trill, J. J., Hay, D. W, Ohlstein, E. H., Bergsma, D. J. and Douglas, S. A. (1999) Human urotensin-II is a potent vasoconstrictor and agonist for the orphan receptor GPR14. Nature 401, 282-286

10 Ziltener, P., Mueller, C., Haenig, B., Scherz, M. W. and Nayler, O. (2002) Urotensin II mediates ERK1/2 phosphorylation and proliferation in GPR14transfected cell lines. J. Recept. Signal Transduct. Res. 22, 155-168

11 Sauzeau, V., Le Mellionnec, E., Bertoglio, J., Scalbert, E., Pacaud, P. and Loirand, G. (2001) Human urotensin II-induced contraction and arterial smooth muscle cell proliferation are mediated by RhoA and Rho-kinase. Circ. Res. 88, 1102-1104

12 Liu, Q., Pong, S. S., Zeng, Z., Zhang, Q., Howard, A. D., Williams, D. L., Jr., Davidoff, M., Wang, R., Austin, C. P., McDonald, T. P., Bai, C., George, S. R., Evans, J. F. and Caskey, C. T. (1999) Identification of urotensin II as the 
endogenous ligand for the orphan G-protein-coupled receptor GPR14. Biochem. Biophys. Res. Commun. 266, 174-178

13 Jégou, S., Cartier, D., Dubessy, C., Gonzalez, B. J., Chatenet, D., Tostivint, H., Scalbert, E., Leprince, J., Vaudry, H. and Lihrmann, I. (2006) Localization of the urotensin II receptor in the rat central nervous system. J. Comp. Neurol. 495, 21-36

14 Do Rego, J. C., Leprince, J., Scalbert, E., Vaudry, H. and Costentin, J. (2008) Behavioral actions of urotensin-II. Peptides 29, 838-844

15 Nothacker, H. P. and Clark, S. (2005) From heart to mind. The urotensin II system and its evolving neurophysiological role. FEBS. J. 272, 5694-5702

16 Volterra, A. and Meldolesi, J. (2005) Astrocytes, from brain glue to communication elements: the revolution continues. Nat. Rev. Neurosci. 6, 626640

17 Guidotti, A., Forchetti, C. M., Corda, M. G., Konkel, D., Bennett, C. D. and Costa, E. (1983) Isolation, characterization, and purification to homogeneity of an endogenous polypeptide with agonistic action on benzodiazepine receptors. Proc. Natl. Acad. Sci. USA 80, 3531-3535

18 Gandolfo, P., Patte, C., Thoumas, J. L., Leprince, J., Vaudry, H. and Tonon, M. C. (1999) The endozepine ODN stimulates [3H]thymidine incorporation in cultured rat astrocytes. Neuropharmacology 38, 725-732

19 Masmoudi, O., Gandolfo, P., Leprince, J., Vaudry, D., Fournier, A., PatteMensah, C., Vaudry, H. and Tonon, M. C. (2003) Pituitary adenylate cyclaseactivating polypeptide (PACAP) stimulates endozepine release from cultured rat astrocytes via a PKA-dependent mechanism. FASEB J. 17, 17-27

20 Masmoudi, O., Gandolfo, P., Tokay, T., Leprince, J., Ravni, A., Vaudry, H. and Tonon, M. C. (2005) Somatostatin down-regulates the expression and release of endozepines from cultured rat astrocytes via distinct receptor subtypes. J. Neurochem. 94, 561-571

21 Takahashi, K., Totsune, K., Murakami, O. and Shibahara, S. (2001) Expression of urotensin II and urotensin II receptor mRNAs in various human tumor cell lines and secretion of urotensin II-like immunoreactivity by SW-13 adrenocortical carcinoma cells. Peptides 22, 1175-1179

22 Castel, H., Diallo, M., Chatenet, D., Leprince, J., Desrues, L., Schouft, M. T., Fontaine, M., Dubessy, C., Lihrmann, I., Scalbert, E., Malagon, M., Vaudry, H., Tonon, M. C. and Gandolfo, P. (2006) Biochemical and functional characterization of high-affinity urotensin II receptors in rat cortical astrocytes. J. Neurochem. 99, 582-595

23 Lin, Y., Tsuchihashi, T., Matsumura, K., Fukuhara, M., Ohya, Y., Fujii, K. and Iida, M. (2003) Central cardiovascular action of urotensin II in spontaneously hypertensive rats. Hypertens. Res. 26, 839-845

24 Desrues, L., Lefebvre, T., Diallo, M., Gandolfo, P., Leprince, J., Chatenet, D., Vaudry, H., Tonon, M. C. and Castel, H. (2008) Effect of GABA A receptor activation on UT-coupled signaling pathways in rat cortical astrocytes. Peptides 29, 727-734

25 Chatenet, D., Dubessy, C., Leprince, J., Boularan, C., Carlier, L., SégalasMilazzo, I., Guilhaudis, L., Oulyadi, H., Davoust, D., Scalbert, E., Pfeiffer, B., 
Renard, P., Tonon, M. C., Lihrmann, I., Pacaud, P. and Vaudry, H. (2004) Structure-activity relationships on structural conformation of a novel urotensin II-related peptide. Peptides 25, 1819-1830

26 Diallo, M., Jarry, M., Desrues, L., Castel, H., Chatenet, D., Leprince, J., Vaudry, H., Tonon, M. C. and Gandolfo, P. (2008) [Orn(5)]URP acts as a pure antagonist of urotensinergic receptors in rat cortical astrocytes. Peptides 29, 813-819

27 Clozel, M., Binkert, C., Birker-Robaczewska, M., Boukhadra, C., Ding, S. S., Fischli, W., Hess, P., Mathys, B., Morrison, K., Muller, C., Muller, C., Nayler, O., Qiu, C., Rey, M., Scherz, M. W., Velker, J., Weller, T., Xi, J. F. and Ziltener, P. (2004) Pharmacology of the urotensin-II receptor antagonist palosuran (ACT-058362; 1-[2-(4-benzyl-4-hydroxy-piperidin-1-yl)-ethyl]-3-(2methyl-quinolin-4-yl) -urea sulfate salt): first demonstration of a pathophysiological role of the urotensin System. J. Pharmacol. Exp. Ther. 311, 204-212

28 Ayoub, M. A., Damian, M., Gespach, C., Ferrandis, E., Lavergne, O., De Wever, O., Baneres J.L., Pin J.P. and Prevost, G.P. (2009) Inhibition of heterotrimeric $G$ protein signaling by a small molecule actine on $G \alpha$ subunit. J. Biol. Chem. 284, 29136-29145

29 Ayoub, M. A., Couturier, C., Lucas-Meunier, E., Angers, S., Fossier, P., Bouvier, M. and Jockers, R. (2002) Monitoring of ligand-independent dimerization and ligand-induced conformational changes of melatonin receptors in living cells by bioluminescence resonance energy transfer. J. Biol. Chem. 277, 21522-21528

30 Ayoub, M. A., Maurel, D., Binet, V., Fink, M., Prézeau, L., Ansanay, H. and Pin, J.P. (2007) Real-time Analysis of agonist-induced activation of proteaseactivated receptor $1 / \mathrm{G} \alpha \mathrm{i} 1$ protein complex measured by bioluminescence resonance energy transfer in living cells. Mol. Pharmacol. 71, 1329-1340

31 Gales, C., Van Durm, J. J., Schaak, S., Pontier, S., Percherancier, Y., Audet, M., Audet, M., Paris, H. and Bouvier, M. (2006) Probing the activatinopromoted structural rearrangements in preassembled receptor-G protein complexes. Nat. Struct. Mol. Biol. 13, 778-786

32 Song, W., McDonald, J., Camarda, V., Calo, G., Guerrini, R., Marzola, E., Thompson, J. P., Rowbotham, D. J. and Lambert, D. G. (2006) Cell and tissue responses of a range of Urotensin II analogs at cloned and native urotensin II receptors. Evidence for coupling promiscuity. Naunyn Schmiedebergs Arch. Pharmacol. 373, 148-157

33 Conlon, J. M., Tostivint, H. and Vaudry, H. (1997) Somatostatin- and urotensin II-related peptides: molecular diversity and evolutionary perspectives. Regul. Pept. 69, 95-103

34 Spier, A. D. and de Lecea, L. (2000) Cortistatin: a member of the somatostatin neuropeptide family with distinct physiological functions. Brain. Res. Brain. Res. Rev. 33, 228-241

35 Marchese, A., Heiber, M., Nguyen, T., Heng, H. H., Saldivia, V. R., Cheng, R., Murphy, P. M., Tsui, L. C., Shi, X., Gregor, P., George, S. R., O'Dowd, B. F. and Docherty, J. M. (1995) Cloning and chromosomal mapping of three novel 
genes, GPR9, GPR10, and GPR14, encoding receptors related to interleukin 8, neuropeptide $\mathrm{Y}$, and somatostatin receptors. Genomics 29, 335-344

36 Nothacker, H. P., Wang, Z., McNeill, A. M., Saito, Y., Merten, S., O'Dowd, B., Duckles, S. P. and Civelli, O. (1999) Identification of the natural ligand of an orphan G-protein-coupled receptor involved in the regulation of vasoconstriction. Nat. Cell. Biol. 1, 383-385

37 Feindt, J., Becker, I., Blomer, U., Hugo, H. H., Mehdorn, H. M., Krisch, B. and Mentlein, R. (1995) Expression of somatostatin receptor subtypes in cultured astrocytes and gliomas. J. Neurochem. 65, 1997-2005

38 Malagon, M. M., Molina, M., Gahete, M. D., Duran-Prado, M., MartinezFuentes, A. J., Alcain, F. J., Tonon, M. C., Leprince, J., Vaudry, H., Castano, J. P. and Vazquez-Martinez, R. (2008) Urotensin II and urotensin II-related peptide activate somatostatin receptor subtypes 2 and 5. Peptides 29, 711-720

39 Verkhratsky, A. and Steinhauser, C. (2000) Ion channels in glial cells. Brain Res. Brain Res. Rev. 32, 380-412

40 Clark, S. D., Nothacker, H. P., Blaha, C. D., Tyler, C. J., Duangdao, D. M., Grupke, S. L., Helton, D. R., Leonard, C. S. and Civelli, O. (2005) Urotensin II acts as a modulator of mesopontine cholinergic neurons. Brain Res. 1059, 139148

41 Huitron-Resendiz, S., Kristensen, M. P., Sanchez-Alavez, M., Clark, S. D., Grupke, S. L., Tyler, C., Suzuki, C., Nothacker, H. P., Civelli, O., Criado, J. R., Henriksen, S. J., Leonard, C. S. and de Lecea, L. (2005) Urotensin II modulates rapid eye movement sleep through activation of brainstem cholinergic neurons. J. Neurosci. 25, 5465-5474

42 MacVicar, B. A. and Tse, F. W. (1988) Norepinephrine and cyclic adenosine 3':5'-cyclic monophosphate enhance a nifedipine-sensitive calcium current in cultured rat astrocytes. Glia 1, 359-365

43 Elshourbagy, N. A., Douglas, S. A., Shabon, U., Harrison, S., Duddy, G., Sechler, J. L., Ao, Z., Maleeff, B. E., Naselsky, D., Disa, J. and Aiyar, N. V. (2002) Molecular and pharmacological characterization of genes encoding urotensin-II peptides and their cognate G-protein-coupled receptors from the mouse and monkey. Br. J. Pharmacol. 136, 9-22

44 Saetrum Opgaard, O., Nothacker, H., Ehlert, F. J. and Krause, D. N. (2000) Human urotensin II mediates vasoconstriction via an increase in inositol phosphates. Eur. J. Pharmacol. 406, 265-271

45 Brailoiu, E., Brailoiu, G. C., Miyamoto, M. D. and Dun, N. J. (2003) The vasoactive peptide urotensin II stimulates spontaneous release from frog motor nerve terminals. Br. J. Pharmacol. 138, 1580-1588

46 Douglas, S. A., Naselsky, D., Ao, Z., Disa, J., Herold, C. L., Lynch, F. and Aiyar, N. V. (2004) Identification and pharmacological characterization of native, functional human urotensin-II receptors in rhabdomyosarcoma cell lines. Br. J. Pharmacol. 142, 921-932

47 Hermans, E. (2003) Biochemical and pharmacological control of the multiplicity of coupling at G-protein-coupled receptors. Pharmacol. Ther. 99, $25-44$ 
48 Perez-Reyes, E. (2003) Molecular physiology of low-voltage-activated T-type calcium channels. Physiol. Rev. 83, 117-161

49 Latour, I., Hamid, J., Beedle, A. M., Zamponi, G. W. and Macvicar, B. A. (2003) Expression of voltage-gated $\mathrm{Ca} 2+$ channel subtypes in cultured astrocytes. Glia 41, 347-353

50 Fern, R. (1998) Intracellular calcium and cell death during ischemia in neonatal rat white matter astrocytes in situ. J. Neurosci. 18, 7232-7243

51 Hirose, K., Kadowaki, S., Tanabe, M., Takeshima, H. and Iino, M. (1999) Spatiotemporal dynamics of inositol 1,4,5-trisphosphate that underlies complex $\mathrm{Ca} 2+$ mobilization patterns. Science 284, 1527-1530

52 Itoh, T., Seki, N., Suzuki, S., Ito, S., Kajikuri, J. and Kuriyama, H. (1992) Membrane hyperpolarization inhibits agonist-induced synthesis of inositol 1,4,5-trisphosphate in rabbit mesenteric artery. J. Physiol.451, 307-328

53 McLaughlin, S., Wang, J., Gambhir, A. and Murray, D. (2002) PIP(2) and proteins: interactions, organization, and information flow. Annu. Rev. Biophys. Biomol. Struct. 31, 151-175

54 Qi, J. S., Minor, L. K., Smith, C., Hu, B., Yang, J., Andrade-Gordon, P. and Damiano, B. (2005) Characterization of functional urotensin II receptors in human skeletal muscle myoblasts: comparison with angiotensin II receptors. Peptides 26, 683-690

55 Wymann, M.P., Bjorklof, K., Calvez, R., Finan, P., Thomast, M., Trifilieff, A., Barbier, M., Altruda, F., Hirsch, E. and Laffargue, M. (2003) Phosphoinositide 3-kinase gamma: a key modulator in inflammation and allergy. Biochem. Soc. Trans. 31, 275-280

56 Gao, S., Shah, A., Oh, Y.B., Park, W.H. and Kim, S.H. (2009) Urotensin II stimulates high frequency-induced ANP secretion via PLC-PI 3K-PKC pathway. Peptides 30, 1874-1881

57 Proulx, C.D., Holleran, B.J., Lavigne, P., Esher, E., Guillemette, G. and Leduc R. (2008) Biological properties and functional determinants of the urotensin II receptor. Peptides 29, 691-699

58 Sofroniew, M.V. (2009) Molecular dissection of reactive astrogliosis and glial scar formation. Trends Neurosci. 32, 638-647

59 Shi, L., Ding, W., Li, D., Wang, Z., Jiang, H., Zhang, J. and Tang, C. (2006) Proliferation and anti-apoptotic effects of human urotensin II on human endothelial cells. Atherosclerosis 188, 260-264 


\section{Figure legends}

Figure 1 Comparison of the primary structures of rat and human urotensin II (UII), urotensin II-related peptide (URP) and somatostatin-14.

Common residues are indicated in bold characters.

Figure 2 Displacement curves and binding parameter tables comparing competition of $\left[{ }^{125} \mathrm{I}\right] \mathrm{UII}$ and $\left[{ }^{125} \mathrm{I}\right.$-Tyr $\left.{ }^{0}, \mathrm{D}-\mathrm{Trp}^{8}\right]$ somatostatin-14 binding by UII, URP and somatostatin-14 on cultured rat astrocytes.

(a) Cells were incubated for $3 \mathrm{~h}$ at $22^{\circ} \mathrm{C}$ with $0.2 \mathrm{nM}$ of $\left[{ }^{125} \mathrm{I}\right] \mathrm{UII}$ in the absence or presence of graded concentrations ( $1 \mathrm{pM}$ to $1 \mu \mathrm{M}$ ) of URP ( $\mathbf{a})$ or UII ( $\square$ ). (b) Cells were incubated for $3 \mathrm{~h}$ at $22^{\circ} \mathrm{C}$ with $0.4 \mathrm{nM}$ of $\left[{ }^{125} \mathrm{I}-\mathrm{Tyr}^{0}, \mathrm{D}-\mathrm{Trp}^{8}\right]$ somatostatin-14 in the absence or presence of graded concentrations of URP $(\mathbf{m}, 10 \mathrm{pM}$ to $10 \mu \mathrm{M})$, UII $(\bullet, 3 \mathrm{nM}$ to $30 \mu \mathrm{M})$ or somatostatin-14 $(\square, 10 \mathrm{pM}$ to $0.3 \mu \mathrm{M})$. Data are mean of three to five independent experiments performed in triplicate. $K$, dissociation constant; $n_{\mathrm{H}}$, Hill coefficient.

Figure 3 Effects of URP and UII on the resting membrane potential and on the release of octadecaneuropeptide immunoreactivity (ODN-LI) from cultured rat astrocytes.

(a) Typical voltage responses to URP and UII (100 nM, 2 min, each) obtained in the amphotericin B-perforated configuration with the current-clamp mode. Hyperpolarizing pulses ( $2 \mathrm{pA}, 10 \mathrm{~ms}, 0.125 \mathrm{~Hz}$ ) were applied to monitor the cell input resistance. (b) Quantitative analysis of URP- and UII-induced membrane depolarizations. (c) Cells were incubated for $1 \mathrm{~h}$ in the absence or presence of graded concentrations $(0.1 \mathrm{nM}, 10 \mathrm{nM}, 1 \mu \mathrm{M})$ of URP or UII. Data are mean \pm S.E.M. of three to twelve independent experiments. *, $p<0.05$; **, $p<0.01$; one way ANOVA followed by a Dunnett's post-hoc test. 
Figure 4 Mechanisms of URP- or UII-induced increase of $\left[\mathrm{Ca}^{2+}\right]_{c}$ in cultured rat astrocytes.

Cells were loaded with fluo-4 AM (40 min) and exposed to PTX $(0.2 \mu \mathrm{g} / \mathrm{mL}, \mathbf{a})$, U73122 (10 $\mu \mathrm{M}, \mathbf{b}), 2$-APB $(50 \mu \mathrm{M}, \mathbf{c})$, EGTA (3 mM, d), mibefradil $(1 \mu \mathrm{M}, \mathbf{e})$, nifedipine $(1 \mu \mathrm{M}, \mathbf{f})$ or $\omega$-conotoxin GVIA $(1 \mu \mathrm{M}, \mathbf{g})$ (white histograms) and/or to URP or UII (0.3 $\mu \mathrm{M}$, each, dashed/colored histograms). Data are expressed as percentages of the corresponding control values in the absence of blockers and peptides. Data are mean \pm S.E.M. of at least 7 independent experiments. ${ }^{*}, \mathrm{p}<0.05$; $* *, \mathrm{p}<0.01 ; * * *, \mathrm{p}<0.001 ; \mathrm{NS}$, non-significant; one way ANOVA followed by a Dunnett's post-hoc test.

\section{Figure 5 Divergent effects of URP and UII on $\left[\mathrm{Ca}^{2+}\right]_{c}$ in cultured rat astrocytes.}

(a) Cells were loaded with fluo-4 AM (40 min) and exposed to graded concentrations of UII or URP ( $1 \mathrm{pM}, 1 \mathrm{nM}, 10 \mathrm{nM}, 0.1 \mu \mathrm{M}$ and $1 \mu \mathrm{M}$, each). Representative recordings of cells exposed to URP (left) and UII (middle). Dose response curve of the mean of maximum amplitude of $\left[\mathrm{Ca}^{2+}\right]_{\mathrm{c}}$ transient induced by URP or UII of at least 10 independent experiments (right). The results are expressed as percentages of the corresponding control values in the absence of peptides. (b and c) Cells were loaded with fura-2 AM (30 min) and perfused ( $100 \mathrm{sec})$ with URP $(0.1 \mu \mathrm{M}, \mathbf{b})$ or UII $(0.1$ $\mu \mathrm{M}, \mathbf{c})$. Galeries of images illustrate the time course change of fluorescence before perfusion (control), at the maximum amplitude (peak), at $300 \mathrm{sec}$ and at $400 \mathrm{sec}$ of recording. Bar graphs represent means of response at peak, at 300 and at $400 \mathrm{sec}$ of recording. Curves show typical recordings of single astrocytes responding to URP (b) and UII (c). The results are expressed as percentages of the corresponding control values in the absence of peptide (control). UII or URP vs control, *p $<0.05 ; * * p<$ 0.01 ; ***; p < 0.001; one way ANOVA followed by a Dunnett's post-hoc test. Mean values at 300 or $400 \mathrm{sec} v s$ peak, ${ }^{\#}, \mathrm{p}<0.01$; NS, non-significant; non-parametric Friedman's test. 
Figure 6 Distinct activities of URP and UII on PIP metabolism in cultured rat astrocytes.

Cells were incubated with $\left[{ }^{3} \mathrm{H}\right]$ inositol in the absence or presence of test substances. (a) Effects of graded concentrations of URP and UII (1 pM to $1 \mu \mathrm{M}$, each). (b) Comparison of the effect of URP (10 nM), UII (10 nM) or URP+UII (10 nM, each). (c) Effect of PTX $(0.2 \mu \mathrm{g} / \mathrm{mL}, 18 \mathrm{~h})$ on URP- and UII- (100 $\mathrm{nM}$, each) induced $\left[{ }^{3} \mathrm{H}\right]$ inositol incorporation. Data are mean \pm S.E.M. of four independent experiments performed in triplicate. PTX, URP or UII vs control, *p $<0.05$; * $\mathrm{p}<0.01$; $* * * \mathrm{p}<0.001$; NS, not statistically different from the control; UII vs URP, ${ }^{\#} \mathrm{p}<0.05 ;{ }^{\# \#} \mathrm{p}<0.001$; UII or URP vs UII+PTX or URP+PTX, ${ }^{\dagger} \mathrm{p}<0.05$; one way ANOVA followed by a Dunnett's post-hoc test.

Figure 7 BRET kinetic analysis of the effect of UII and URP on $G_{0}$ protein activation.

Cells transiently coexpressing $\mathrm{G}_{\alpha_{0}}$-Rluc, $\gamma_{2}$-YFP with hUT (a and b) or PAR-1 (c) were used for BRET experiment. Repetitive signals were recorded during $200 \mathrm{sec}$ immediately before and after injection (arrow) of PBS or Thrombin (Thr, $50 \mathrm{U} / \mathrm{mL}$ ) on hUT expressing HEK293 (HEK293-hUT, a), UII $(0.1 \mu \mathrm{M})$ or URP $(0.1 \mu \mathrm{M})$ on HEK293-hUT (b) and Thr, UII or URP on HEK293 expressing PAR-1(HEK293-PAR$1, \mathbf{c})$.

Figure 8 Effects of UII and URP on cultured rat astrocyte viability.

(a) Non-synchronized cells were incubated for $24 \mathrm{~h}$ in the absence or presence of URP (10 nM), UII (10 nM), PACAP (10 nM), IL-1 $(10 \mathrm{ng} / \mathrm{mL})$ or ET-1 (10 nM). (b) Nonsynchronized cells were incubated for $24 \mathrm{~h}$ in the absence or presence of graded concentrations of URP or UII (10 pM to $1 \mu \mathrm{M})$. (c) Synchronized cells were incubated for $24 \mathrm{~h}$ in the absence or presence of graded concentrations of URP or UII ( $0.1 \mathrm{pM}$ to $0.1 \mu \mathrm{M})$. For $\mathbf{a}$ and $\mathbf{b}$, viability was determine with WST-1; for $\mathbf{c}$, the mitogenic activity was determined by counting cell number. The results are expressed as percentages of control values. Data are mean \pm S.E.M of three independent 
experiments performed in quintuplicate. ${ }^{*} \mathrm{p}<0.05$; $* * \mathrm{p}<0.01$; ***p $<0.001$; NS, not statistically different from the control; one way ANOVA followed by a Dunnett's post-hoc test.

Figure 9 Proposed model depicting distinct and common transduction pathways activated by URP and UII on cultured rat astrocytes.

At low concentrations, UII binds a very high affinity site and activates a PTX-sensitive $\mathrm{G}_{\mathrm{i} / \mathrm{o}}$ protein-coupled UT signaling pathway involved in PIP turnover, likely through IP kinases as PI3K, which would be involved in astrocyte proliferation. This specific UT coupling may be also, but in a very less extent, activated by URP. At higher concentrations, URP and UII recruit a high affinity site also attributable to UT that can be both associated to a $\mathrm{G}_{\mathrm{q}} / \mathrm{PLC} / \mathrm{IP}_{3} / \mathrm{Ca}^{2+}$ pathway and $\mathrm{T}$-type voltage-dependent $\mathrm{Ca}^{2+}$ channels. These extra- and intracellular $\mathrm{Ca}^{2+}$ pools appear cross-dependent, and would be involved in astrocyte depolarization and endozepine release. At high concentrations, URP may in addition bind sst expressed by astrocytes, such as sst2. This URP specific activation of sst could synergize the $\left[\mathrm{Ca}^{2+}\right]_{\mathrm{c}}$ increase evoked by UT, and/or counteract the UT-associated proliferation. 


\begin{tabular}{l|ccc}
\multicolumn{1}{c|}{ Peptides } & \multicolumn{3}{|c}{ Sequences } \\
\hline rat UII & QHGT A E C & F W K Y & C I \\
human UII & E T P D C & F W K Y & C V \\
human UII & D C & F W K Y & C V \\
URP & A C & F W K Y & C V \\
Somatostatin-14 & A GC K N F F W K T F T S C \\
\end{tabular}

Figure 1 Jarry et al. 


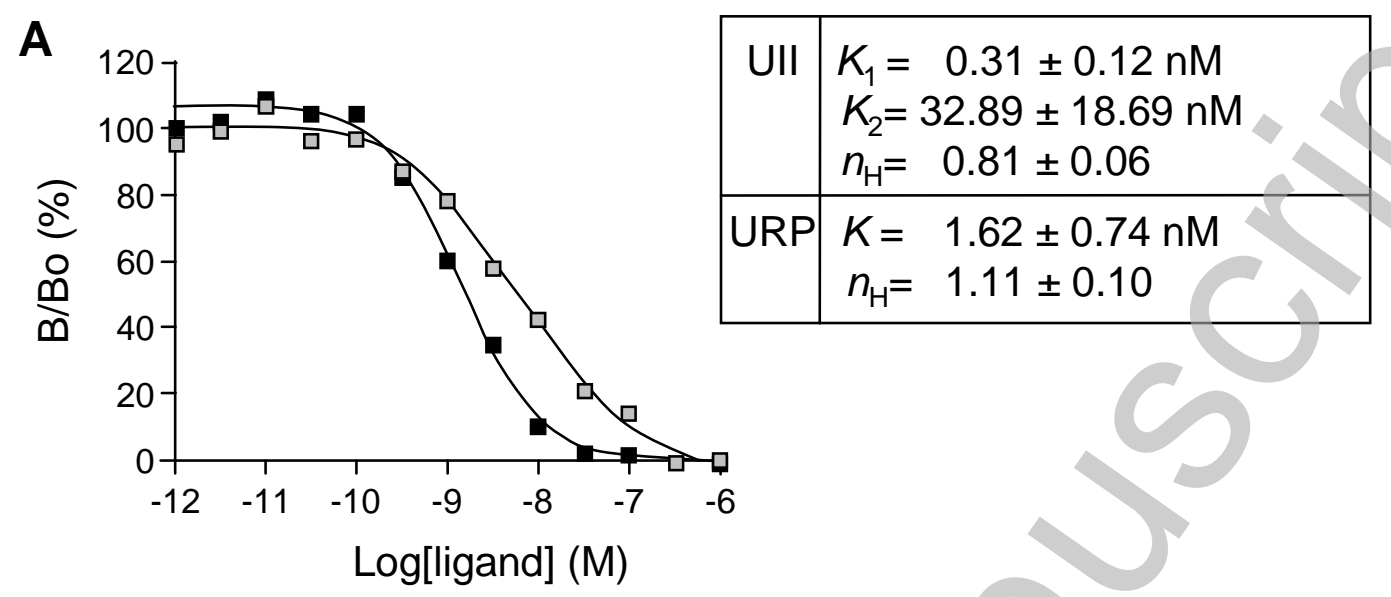

B

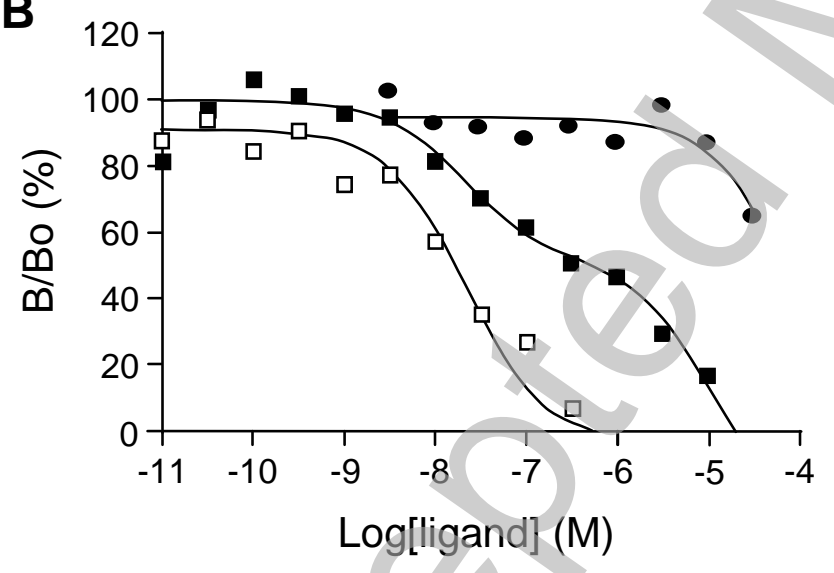

\begin{tabular}{|c|l|}
\hline \multirow{3}{*}{ URP } & $K_{1}=9.16 \pm 5.32 \mathrm{nM}$ \\
& $K_{2}=4.42 \pm 1.72 \mu \mathrm{M}$ \\
& $n_{\mathrm{H}}=0.32 \pm 0.09$ \\
\hline \multirow{2}{*}{ Somatostatin-14 } & $K=36.7 \pm 10.9 \mathrm{nM}$ \\
& $n_{\mathrm{H}}=0.97 \pm 0.07$ \\
\hline
\end{tabular}

Figure 2 
A
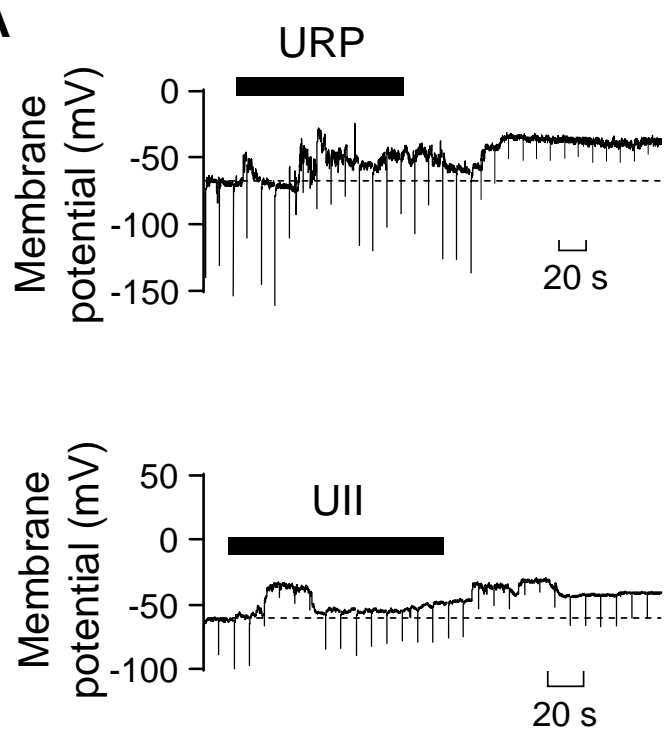

B

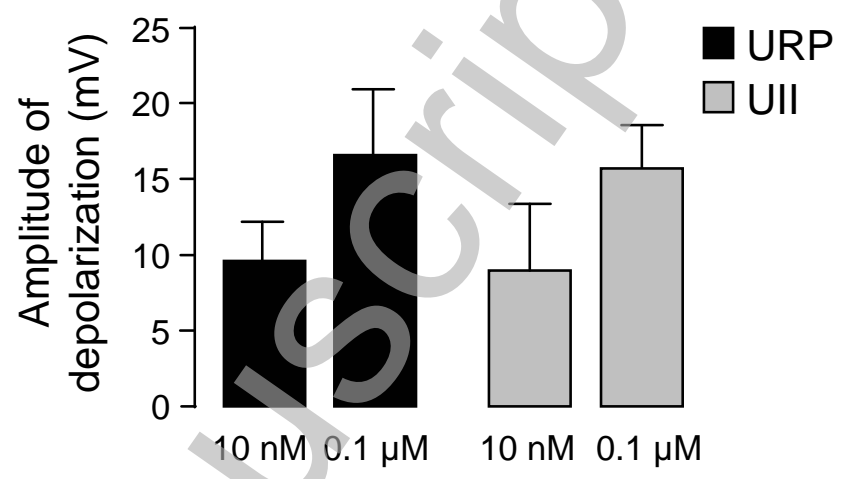

C

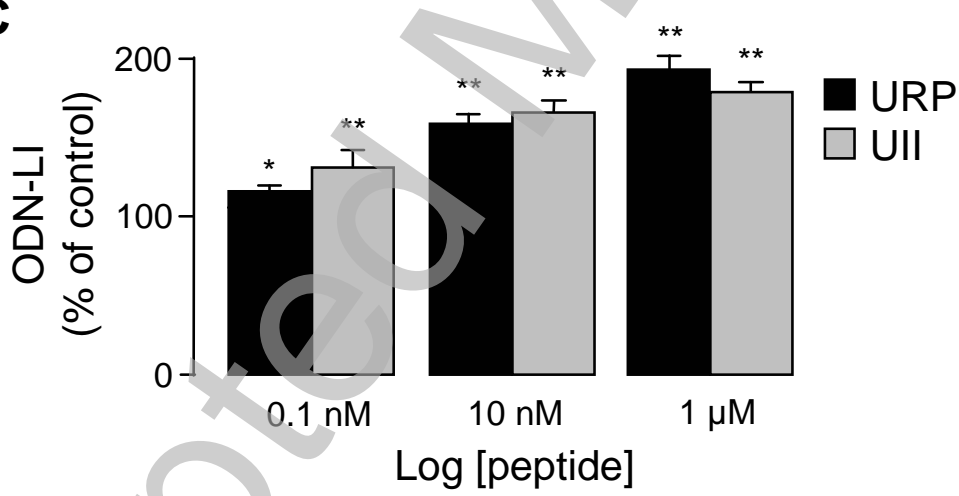

Figure 3

Jarry et al. 
A


B
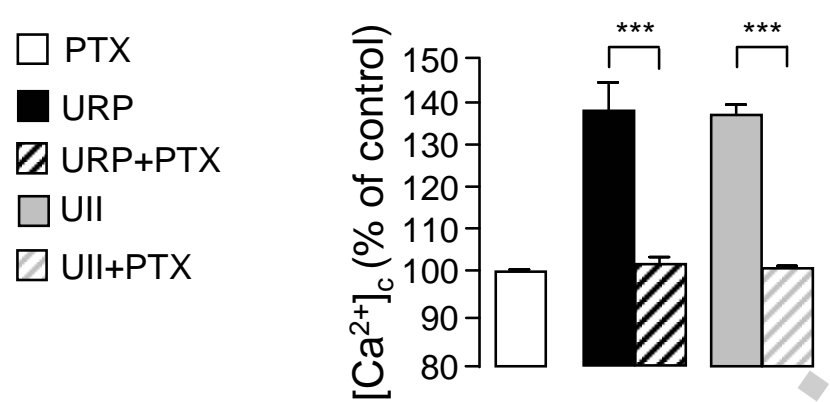

$\square$ U73122

口 URP

Z URP+U73122

$\square$ UII

\UII+U73122

C

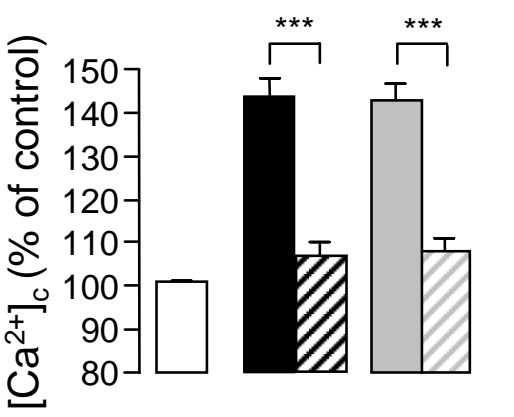

$\square$ 2-APB

URP

$\square \cup R P+2-A P B$

$\square$ UII

$\square$ UII+2-APB

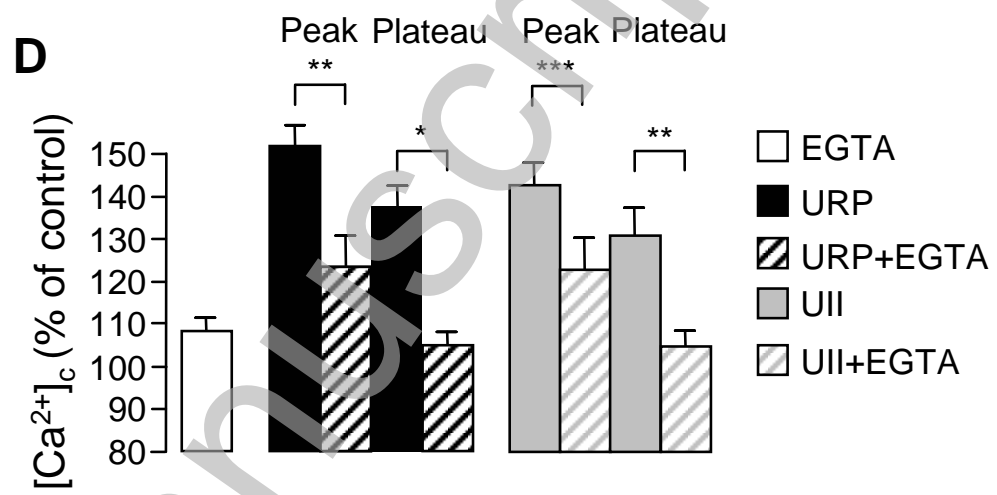

F
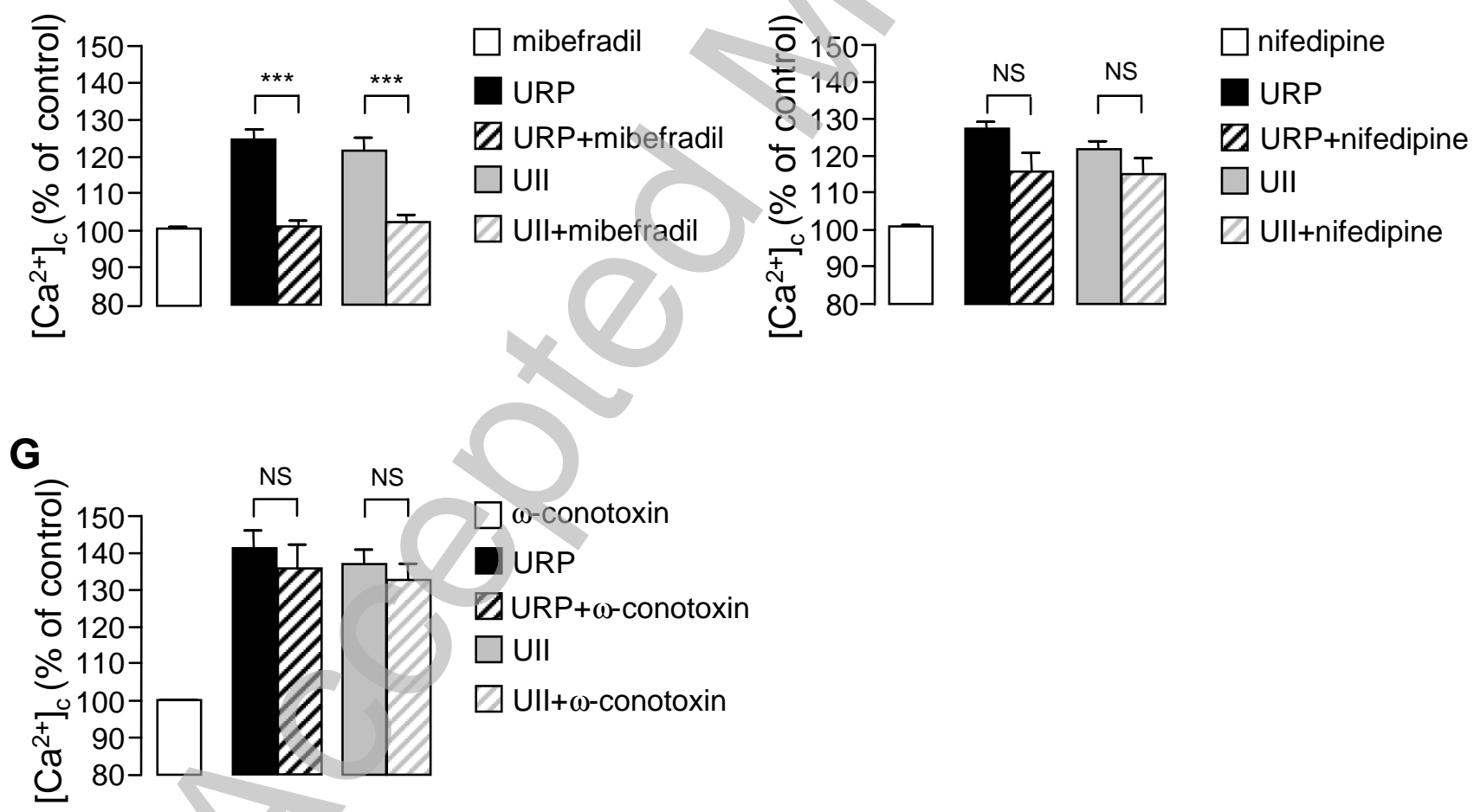

Figure 4 
A
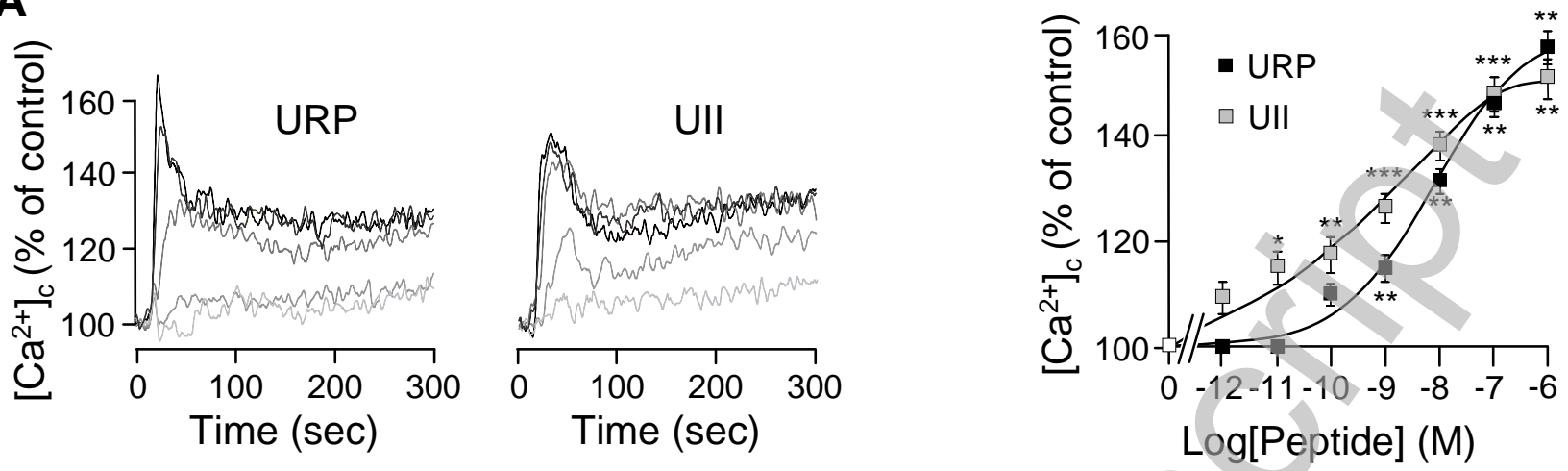

B
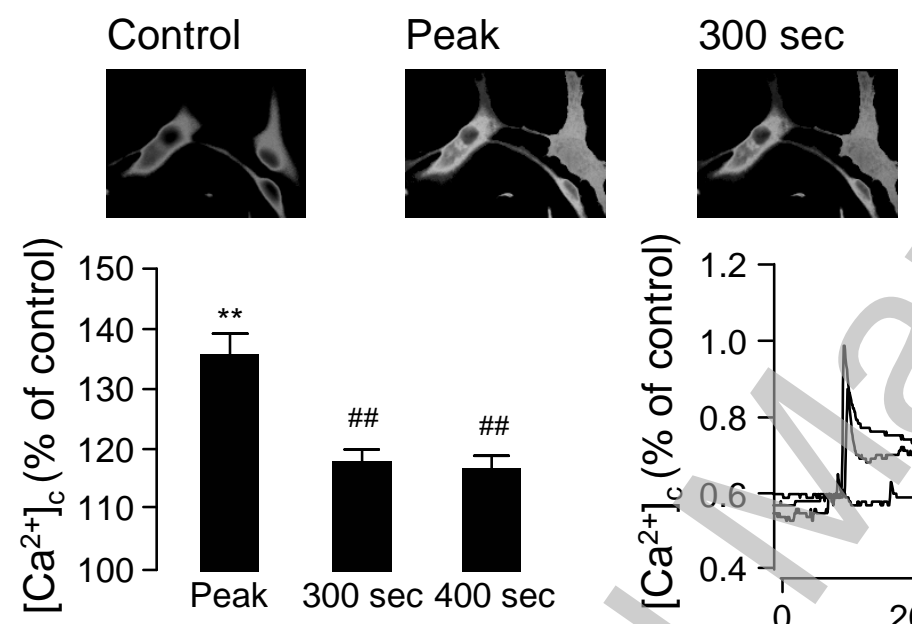

$400 \mathrm{sec}$

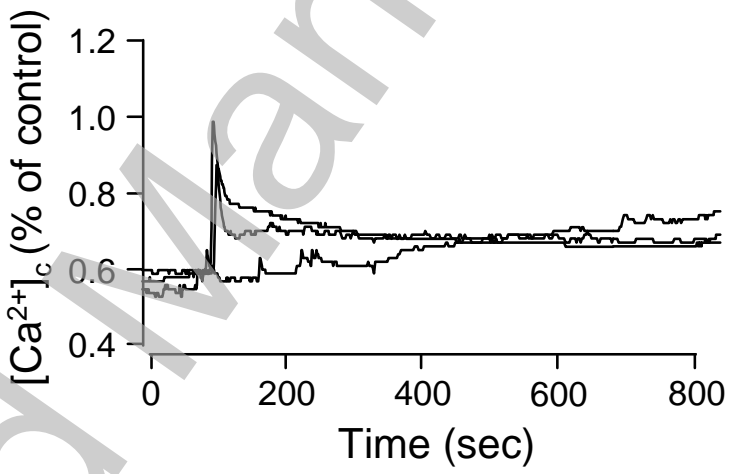

C

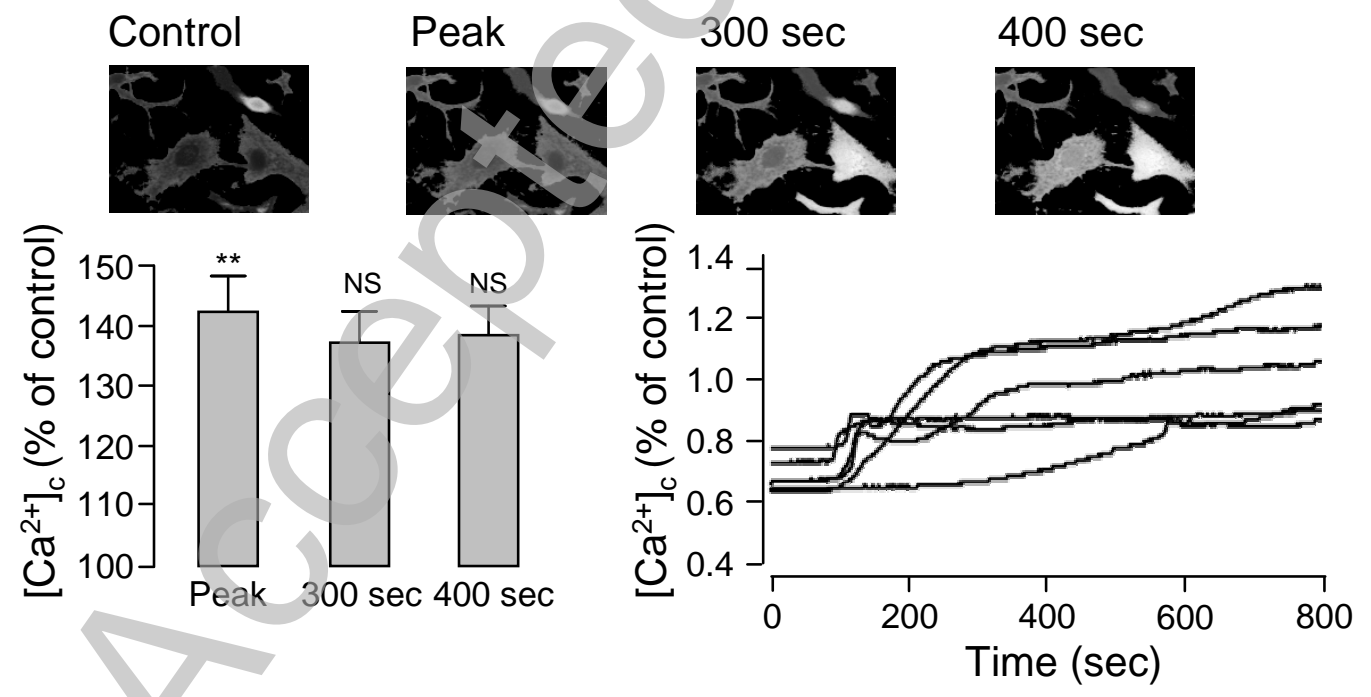

Figure 5

Jarry et al. 
A

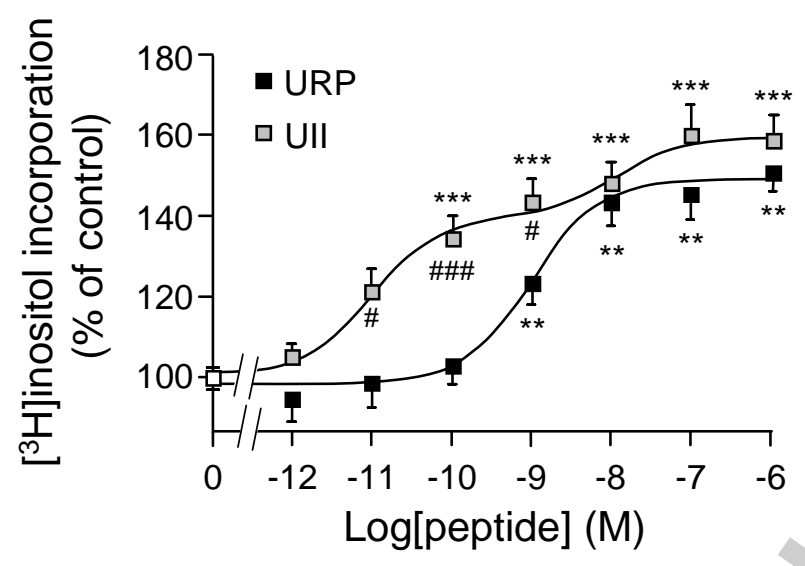

B
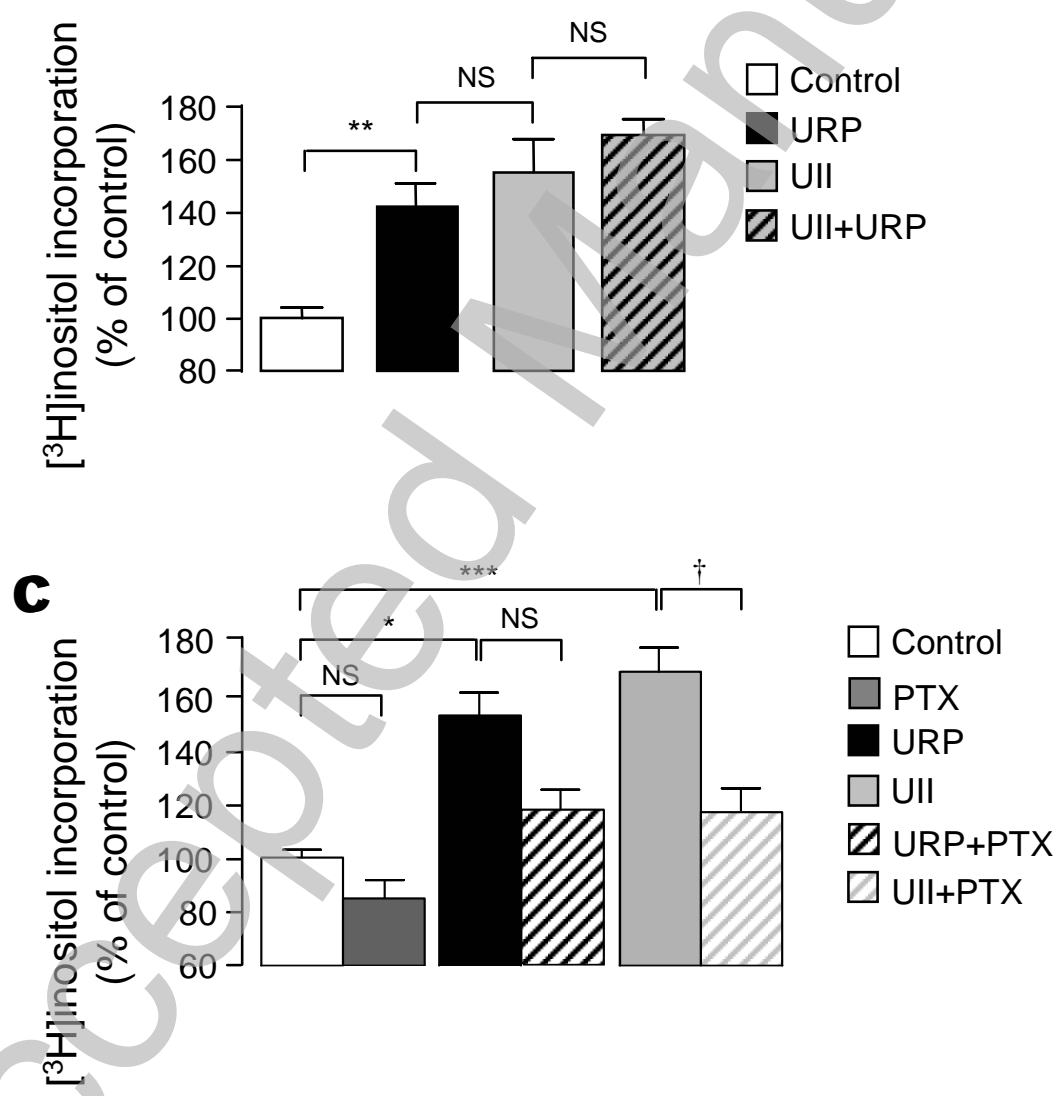

Figure 6 Jarry et al. 
A

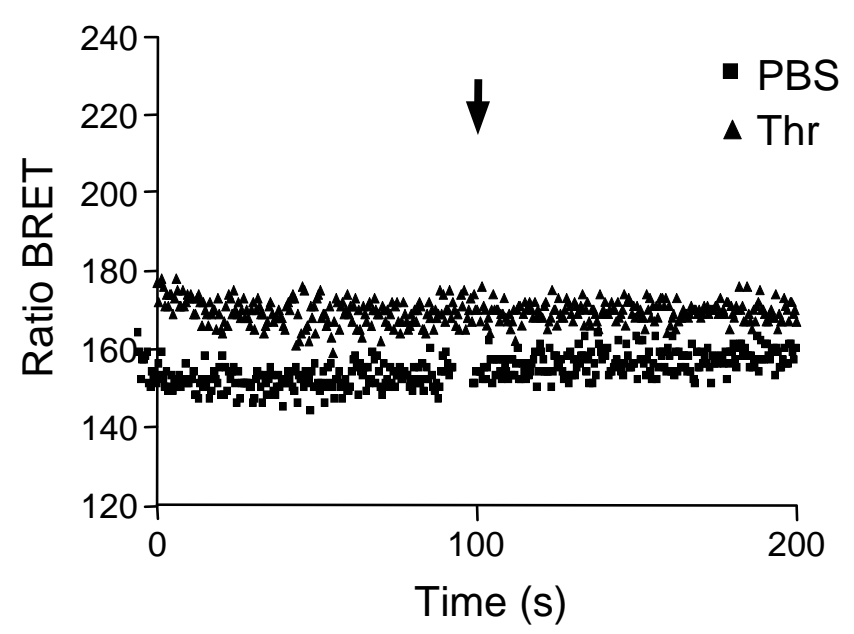

C

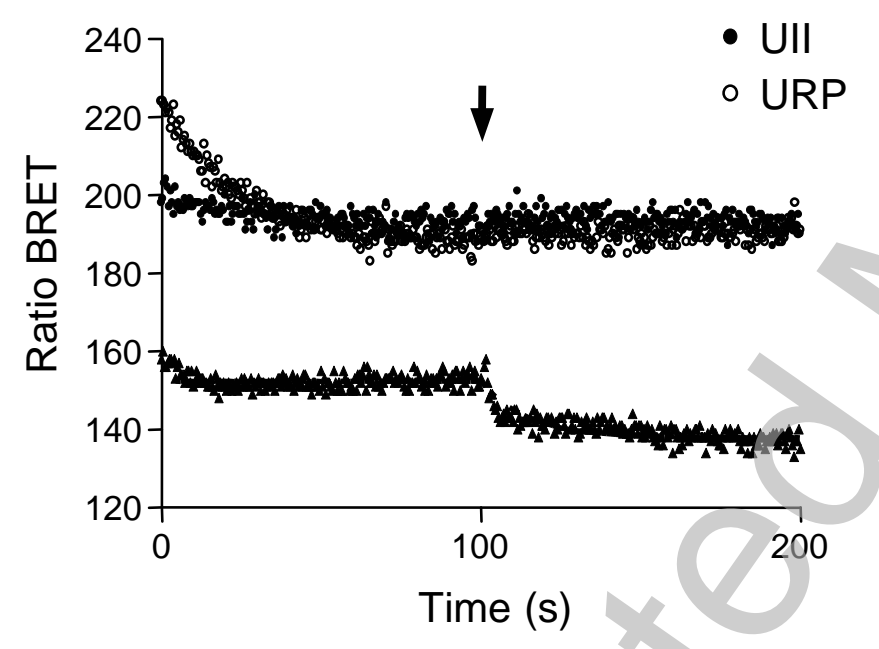

B

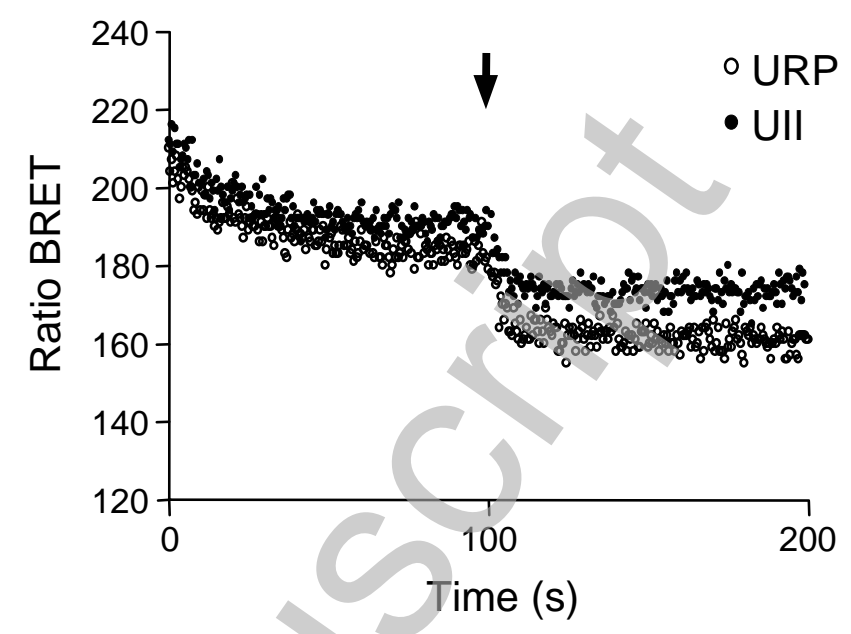




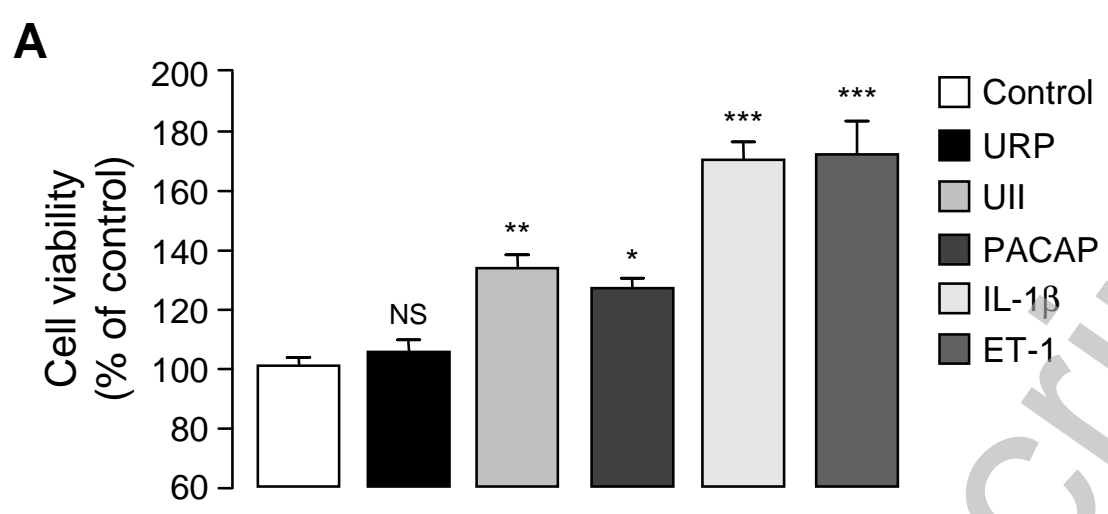

B
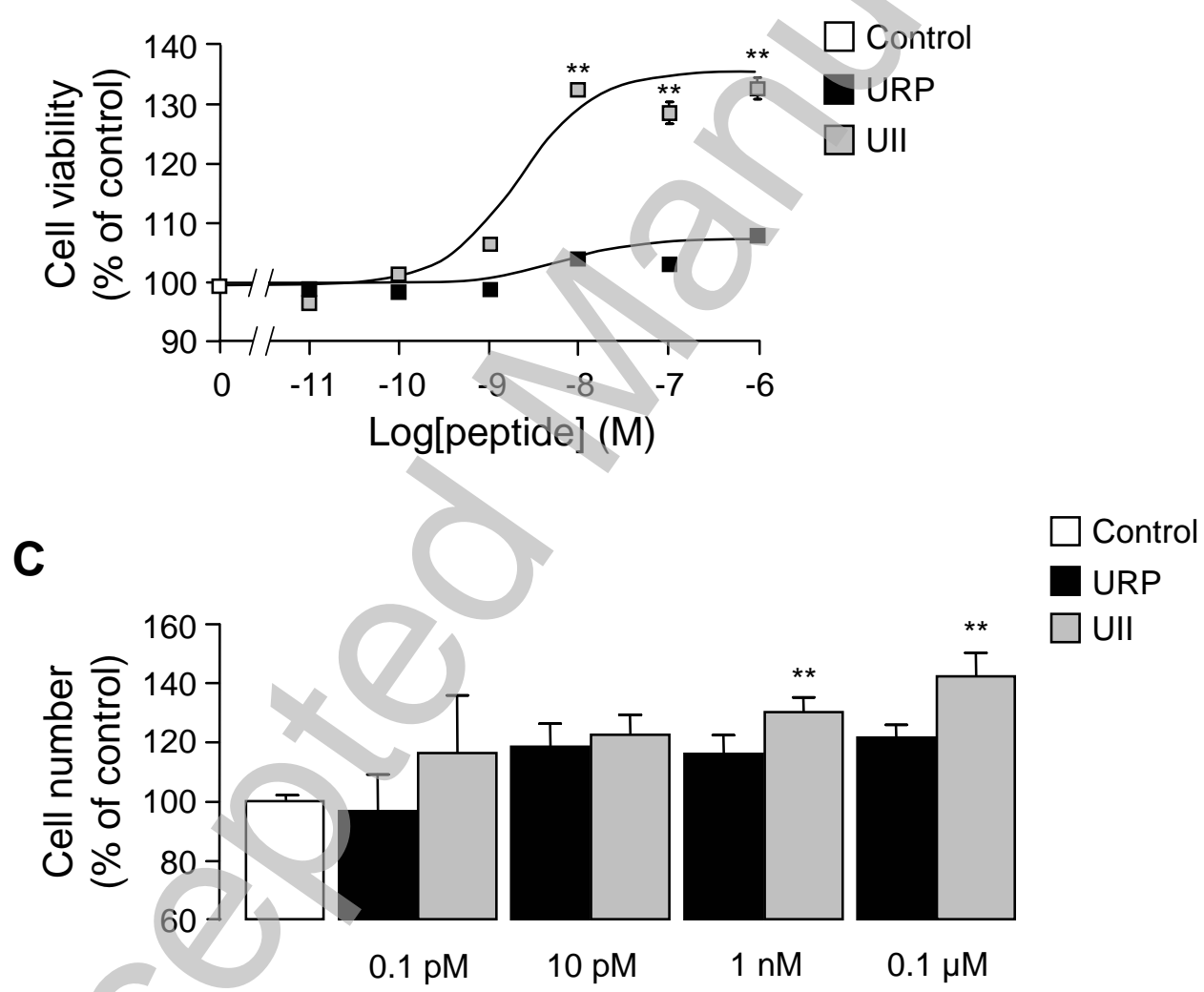

Figure 8 Jarry et al. 
Biochemical Journal Immediate Publication. Published on 02 Mar 2010 as manuscript BJ20090867

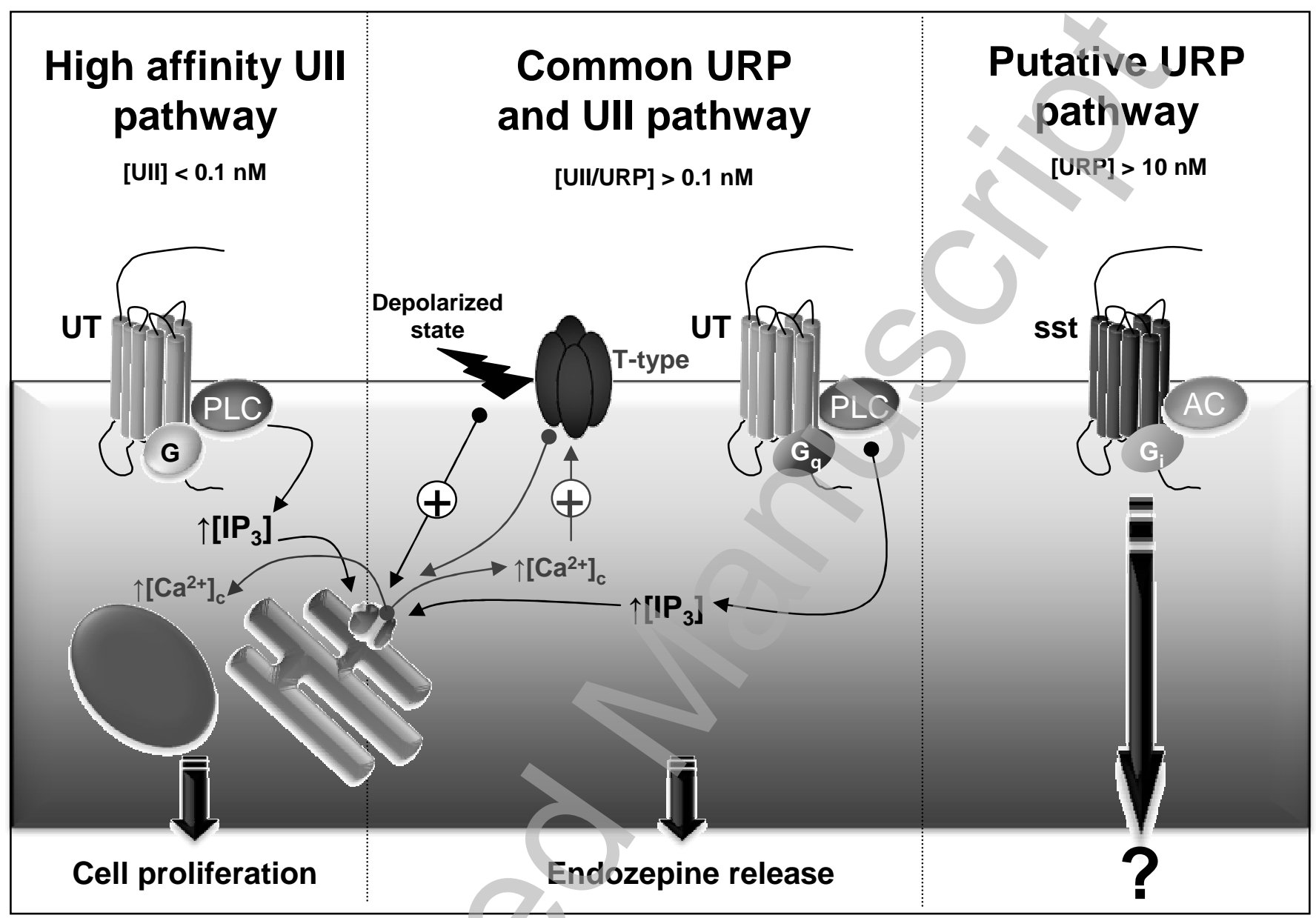

Figure 9

Jarry et al.

Licenced copy. Copying is not permitted, except with prior permission and as allowed by law. ' 2010 The Authors Journal compilation ' 2010 Portland Press Limited 